\title{
Turbidite and conglomerate successions in an Ordovician back-arc basin, Mid-Norwegian Caledonides: a result of long-term staging followed by catastrophic release of sediments
}

\author{
Sverre Henriksen', David Roberts² \& Per-Åge Pedersen ${ }^{3}$ \\ ${ }^{1}$ Statoil Research Center, Rotvoll, Arkitekt Ebbels veg 10, 7005 Trondheim, Norway \\ ${ }^{2}$ Geological Survey of Norway, Postbox 6315 Torgarden, 7491 Trondheim, Norway \\ ${ }^{3}$ Statoil ASA, Sandsli, Sandsliveien 90, 5254 Sandsli, Norway \\ E-mail corresponding author (Sverre Henriksen): shen@statoil.com
}

\begin{abstract}
The Ordovician metasedimentary rocks in the Caledonian nappes in Mid Norway were deposited in a back-arc setting, following ophiolite obduction, uplift and erosion, related to continental uplift and changing directions of subduction during this period. Deep-water conditions were established in the basin and this accommodated a thick succession of variously coarse-grained, conglomeratic and argillaceous sediments. The conglomerates typically display the well-rounded clast material of variable igneous, volcanic, sedimentary and carbonate origin and alternate between being clast-supported and matrix-supported with interbedded sandstone beds. The rounded clasts suggest significant reworking and long-term storage of sediments in the source area before transport into the deeper part of the basin. The basal surface of conglomerates always shows an erosive contact with underlying shales or coarsening-upward sandstone successions. The basal surfaces probably represent sedimentary fairways, where several conglomerate units separated by erosional contacts are stacked on top of each other. The conglomerate successions likely result from episodic release of large quantities of sediments. Between each burst of release, sediments accumulated in alluvial fans, fan deltas and fluvial delta systems along the basin shoreline and carbonate reefs established on the outer shelf. Laterally accreting channel sandstone beds were probably important in setting up sedimentary fairways for the succeeding conglomerates. In the inferred deepest part of the basin, smaller channellised features and thin-bedded turbidites seem to dominate. Channel features and hummocky cross-stratification in shelf to upper slope sandstone beds are alternatively interpreted to result from unidirectional flows and constitute an integral part of the turbidite system. By including all the observed facies within the turbidite system we invoke a depositional model which does not require a eustacy-driven sequence-stratigraphic model for explanation. We rather suggest a tectonic model involving an elevated source area, either volcanic or continental, where erosional products are stored and reworked in the alluvial accommodation zone. These sediments are built up to a threshold level and flushed to the sea by a sudden availability of large amounts of water. The actual cause of this sudden availability of water remains uncertain, but the consequent mixture of water and sediments resulted in a super-concentrated high-energy density current.
\end{abstract}

Keywords: Ordovician, back arc basin, conglomerates, catastrophic floods, turbidites

Received 20. September 2017 / Accepted 12. April 2018 / Published online10. June 2018

\section{Introduction}

The Caledonides of central Norway are especially well known for their fragmented ophiolite assemblages and, in some areas, the overlying, richly fossiliferous, Ordovician to inferred Early Silurian, low-grade metasedimentary rocks (Bergström, 1979, 1997; Bruton \& Bockelie, 1980; Ryan et al., 1980; Neuman \& Bruton, 1989; Neuman et al., 1997). These magmato-sedimentary associations constitute a part of the Upper Allochthon of Caledonide tectonostratigraphy. These are interpreted to represent

Henriksen, S., Roberts, D. \& Pedersen, P.Å. 2018: Turbidite and conglomerate successions in an Ordovician back-arc basin, Mid-Norwegian Caledonides: a result of long-term staging followed by catastrophic release of sediments. Norwegian Journal of Geology 98, 141-164.

https://dx.doi.org/10.17850/njg98-1-09. 
the exotic oceanic terranes of the Iapetus Ocean deriving from far outside the Baltoscandian margin of Baltica, Laurentia, or even an intervening microcontinent (Roberts \& Gee, 1985; Stephens \& Gee, 1989; Roberts et al., 2002; Lippard, \& Roberts, 2010; Hollocher et al., 2012; Nilsson \& Roberts, 2014). Although well known for their paleontology, the Ordovician basinal successions in this part of Norway have received comparatively little attention with regard to their sedimentology and overall development, with a few exceptions (Siedlecka, 1967; Roberts, 1972; Buller \& Johnsen, 1982). As the region has a quite detailed map coverage at 1:50,000 scale, it clearly holds the potential to provide new insight into our current knowledge of deep-marine deposits, basin formation and basin-filling processes.

To partly redress this imbalance, in this contribution we describe the sedimentology and sedimentary development of part of the post-ophiolite, Ordovician to inferred Early Silurian, lithostratigraphical succession of the Åsenfjord district, located $25-40 \mathrm{~km}$ northeast of Trondheim (Fig. 1). The seeds of this present study go back to two, unpublished, Master's theses (Pedersen, 1981; Strømmen, 1983). Both before and since that time, detailed 1:50,000-scale mapping had revealed local features of sedimentology and ichnology that pointed to a deep-marine, depositional environment during the accumulation of these thick successions (Gale \& Roberts, 1974; Roberts, 1969, 1972, 1984). This interpretation was later verified from a more detailed study of trace fossils by Uchman et al. (2005). Subsequent international excursions to the area and supplementary fieldwork over the last thirty years have revealed additional sedimentary features which lend further support to the earlier interpretations. At the same time, these new observations have allowed corrections and additions to be made to the preliminary 1:50,000 map-sheet 'Frosta' (Roberts, 1985), which will be prepared for publication during the coming months.

Our study of the turbidites in the Åsenfjord area has led us to repudiate the traditional eustacy-driven sequence-stratigraphic model for deposition of such sediments. Instead, we favour a model involving longterm storage of erosional products in an alluvial to

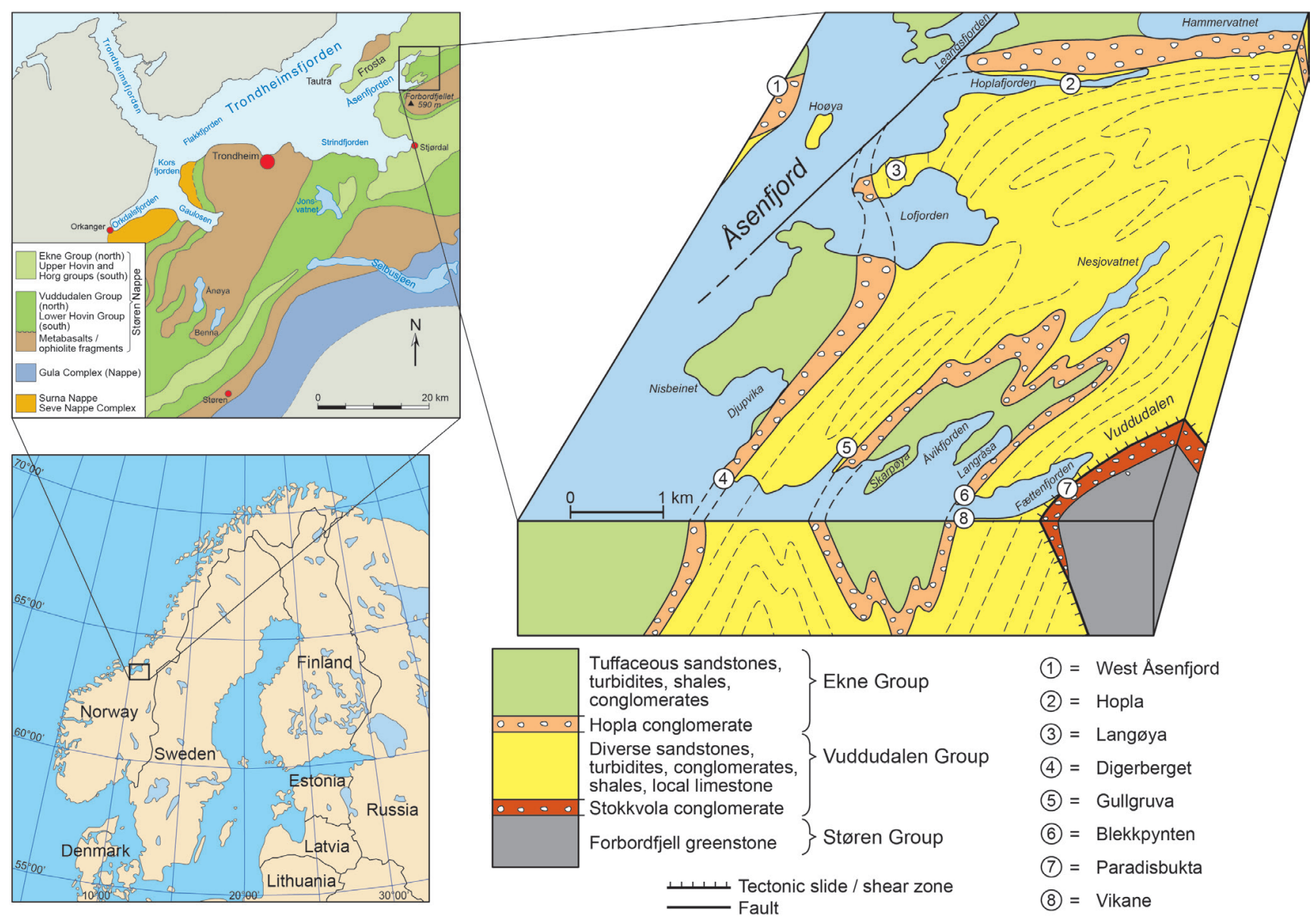

Figure 1. Location of the study area in the inner part of Trondheimsfjorden, Mid Norway. Block diagram with legend shows the lithostratigraphy and also illustrates the main, large-scale, Scandian fold structures in the area. The localities are all on 1:50,000 map-sheet 'Frosta' 1622-2. In some cases, the given localities extend along strike over several tens of metres. All the localities are in UTM zone 32V NR. UTM coordinates for the localities 1-9 are: Loc. 1. 59310-705425; Loc. 2. 59600-705430; Loc. 3. 59420-705290; Loc. 4. 59230-704970; Loc. 5. 59265-704985; Loc. 6. 59490-704940; Loc.7. 59540-704900; Loc. 8. 59290-704765. 
deltaic accommodation zone, wherein such sediments are eventually and catastrophically flushed into the sea by a sudden availability of large amounts of water, thus generating a hyper-concentrated, high-density current. The sequence-stratigraphic line of thinking, and its predefined terminology, has been found unsuitable to describe and interpret the stratigraphy in the study area. Therefore, we have chosen a descriptive and neutral terminology in the following text, where beds and sets of beds constitute genetically linked depositional units. Stacking of units constitute successions of strata that may, or may not, be genetically linked.

\section{Earlier research on turbidite systems}

Our general understanding of sedimentary structures and facies models for turbidite successions was quite advanced and for a large part well established by the 1980s (e.g., Kuenen \& Migliorini, 1950; Kuenen \& Menard, 1952; Sloss, 1963; Mutti \& Ricci-Lucchi, 1975; Payton, 1977; Walker, 1978). The further development of sequence-stratigraphic concepts and the placement of the turbidite system within this framework accelerated during the 1980s and 1990s and major advancements were summed up in significant contributions by Wilgus et al. (1988) and Weimer \& Posamentier (1994). In parallel with this, a growing body of publications on deep-marine turbidite deposits emerged in the scientific community (e.g., Weimer \& Link, 1991; Mutti, 1992; Weimer et al., 1994; Plink-Börklund, et al., 2001). The increased focus on deep-marine deposits and processes was largely driven by the oil industry and the identification of these deposits as exploration targets. Our understanding of deep-water depositional systems has since advanced significantly mainly due to the advent of high-quality 3D seismic data from continental margins worldwide (Posamentier \& Kolla, 2003; Mayall et al., 2006; Janocko et al., 2013; Gong et al., 2015).

Whereas early models of deep-marine systems were largely derived from outcrop studies in active tectonic settings, most of the recent models and interpretations originate in industry-based seismic studies from passive continental margins. The scale of the passive continental margin systems is generally several orders of magnitude larger than any exposed deep-water system onshore. The actual relevance of the outcrop studies from active tectonic settings to the large passive continental-margin basins and vice-versa is thus also a question to bear in mind (e.g., Lien et al., 2003; Higgs, 2015; Henstra et al., 2016).

Most workers, however, have related incision of the shelf and further emplacement of turbidites to the deepmarine environment to a lowstand situation, and indeed, even for the most extreme sedimentation rates this is most likely to happen during a fall in relative sea level. It is however, increasingly recognised that even during a relative sea-level fall, a difference in gradient is necessary to create incision of the highstand shoreface (e.g., Miall, 1991; Posamentier et al., 1992; Schumm, 1993; Bullimore et al., 2005). It is also well known that rivers may flood and become supersaturated with sediments independent of sea level, and deliver sediments directly to deep water if they are close to the shelf edge and can feed directly into the slope. In a basin where super-concentrated/ hyperpycnal flows occur from time to time, the sediment delivery to the shelf and shelf edge may be very high. This may result in accumulation of thick sediment successions at the shelf edge and over-steepening of the slope. These sediments are prone to collapse, and in the case of a hyperpycnal delivery system, the sediment discharge and current velocity may be sufficient to incise the shelf, even during a highstand situation. Indeed, Mulder et al. (2003) documented that a single flood may cause a river to incise $3 \mathrm{~m}$ as far as $2 \mathrm{~km}$ inland of the river mouth without implying sea level fall at all.

If a hyper-concentrated/hyperpycnal river plunges directly into a newly formed slump scar and submarine canyon, the sediment delivery to the deep-marine domain may be efficient as long as the river stays hyperpycnal (Porebski \& Steel, 2006). In the case of a collapse of an over-steepened shelf edge, this will invariably trigger the initial phase of the turbidity current. Several studies (e.g., Hiscott et al., 1997; Mulder et al., 2001; Henriksen et al., 2011) have suggested hyperpycnal flows as an important mechanism for formation and maintenance of submarine canyons in areas of high sediment supply, either as frequent slide-induced surges or by sustained hyperpycnal flows (Mulder et al., 2003). In this scenario, the hyperpycnal flows confined within the incised shelf will set up a sediment fairway that will adjust its gradient towards the lowest point (basin floor). This will imply a stratigraphic base level different from mean sea level. Such a model will only be meaningful if there is a sustained flow from source to sink in the basin (Mutti et al., 2006; Mutti et al., 2009).

The tectonically active and episodically high supply margin discussed in this paper may provide excellent conditions for the formation of well-defined unconformities with only modest changes in relative sea level.

The processes involved in transporting and depositing the sediments, however, are universal and in this study, we aim at utilising the sedimentological and stratigraphic data from a volcanic arc-adjacent basin and propose a depositional model that we believe may have general validity for understanding deep-marine deposits in similar basins. In this, we infer a linked depositional system from alluvial and deltaic to deep marine and the significance of sudden, catastrophic event release of large quantities of sediments stored in the alluvial and nearshore environments.

These sudden releases of large volumes of sediments may be termed a catastrophic event. What a catastrophic event 
really means in the evolution of a geological system, and how to recognise such an event in the rock record, has been a subject of discussion (Mutti et al., 1996; Mulder \& Chapron, 2011). However, catastrophic events do occur and, as suggested in this and other studies, these events appear to be cyclic and affect the equilibrium profile of the depositional system (e.g., Mutti et al., 1996). In a larger perspective, the catastrophic events may be a natural part of the normal evolution of a sedimentary basin, especially where triggered by earthquakes in volcanically active regions.

\section{Geological setting}

\section{General}

The Trondheim Region of central Norway is dominated by a series of nappes or thrust sheets that were transported southeastwards onto the Baltoscandian margin of the Fennoscandian Shield during the SiluroDevonian Scandian orogeny. This has been interpreted to result in the formation and migration of an oceanic island arc above a subduction zone influenced by continentally derived sediments (Slagstad et al., 2014). The Upper Allochthon here comprises three major nappes-from east to west the Meråker, Gula and Støren nappes - that together constitute the Trondheim Nappe Complex (TNC), which in turn occupies a deep depression in the Precambrian crystalline basement (Wolff, 1984; Gee et al., 1985; Hurich et al., 1988). Below the TNC in some areas there are diverse nappes of the Middle Allochthon, most of which have various local names (Gee et al., 1985; Roberts \& Stephens, 2000). The Støren Nappe is particularly well known for its fragmented ophiolites and rich assemblage of Ordovician body fossils. The classical work of Vogt (1945) in the Hølonda-Horg area southwest of Trondheim (Fig. 1) led to the establishment of four major groups, in ascending order the Støren, Lower Hovin, Upper Hovin and Horg groups, ranging in age from Late Cambrian to Late Ordovician and possibly Early Silurian. The ophiolite at the base of the Støren lies with tectonic contact above a generally higher-grade, heterogeneous unit, the Gula Complex of the Gula Nappe (Fig. 1).

In a compilation of the 1:250,000 map-sheet 'Trondheim', Wolff (1976) adopted and extended Vogt's nomenclature over the entire map area, and this fourfold lithostratigraphy was also incorporated into many of the 1:50,000 preliminary (black and white) map-sheets from the region compiled in the 1970s and 80s. Since that time, however, further research and mapping have shown that although the basic subdivisions are still largely acceptable, there are significant and, in places, rapid lithofacies changes along strike from area to area. In addition, parts of successions have been tectonically excised in some areas. This is also the case in the Åsenfjord area, where it has been necessary to adopt a more local lithostratigraphic nomenclature.

\section{The Åsenfiord study area}

The greenschist-facies sedimentary succession of the Åsenfjord area and adjacent Frosta peninsula forms part of the Støren Nappe (Fig. 1). Although the succession has been deformed during three main phases of Mid SilurianEarly Devonian, Scandian folding (Roberts, 1969), the low-grade rocks display surprisingly well preserved sedimentary structures. The oldest rocks in the area are those of the Forbordfjell ophiolite, comprising mainly metabasaltic greenstones with minor trondhjemite, felsic extrusive rocks and gabbro. Zircons from two separate felsic rocks considered to be broadly coeval with the mafic volcanism have yielded $\mathrm{U}-\mathrm{Pb}$ crystallisation ages of circa 485.6 and $488 \mathrm{Ma}$ (Gromet \& Roberts, 2015).

Overlying the ophiolite are two main groups of sedimentary rocks, locally with a volcanic component, which Wolff (1976) named the Lower and Upper Hovin groups, following Vogt's (1945) and Kiær's (1932) nomenclature. On the preliminary 1:50,000 map-sheet 'Frosta', Roberts (1985) retained the term Lower Hovin Group but used the name Ekne Group for the higher unit, following Törnebohm (1896). During ongoing revision of this map-sheet, the term Lower Hovin Group has been replaced by the local name Vuddudalen Group (Figs. $1,2)$. The basal formation of the Vuddudalen Group is the Stokkvola conglomerate (Roberts, 1975), a polymict lithology lying unconformably upon the ophiolite and replete with material eroded from the latter. The clasts are dominated by basaltic greenstone, but there are also pebbles and cobbles (up to $40 \mathrm{~cm}$ across) and subangular blocks of jasper, tuffs, quartz-keratophyre, siltstone, sandstone, carbonate and pelitic rocks, quartzite, chert, trondhjemite and minor gabbro. The matrix is a green to greenish-grey siltstone, generally coarser near the base of the formation and becoming increasingly finer grained and phyllitic towards the top (Fig. 2B).

In the Fættenfjord area, the top of the conglomerate defines a major, basin-scale event in terms of both sedimentology and tectonics. In other areas, shallowmarine green sandstones and shales generally follow equivalents of the Stokkvola conglomerate (e.g., Buller \& Johnsen, 1982), but in our study area a 'fold-fault' or tectonic slide (sensu Fleuty, 1964) is present at the top of the conglomerate and has excised most of the shallowmarine strata. The lowermost lithologies (an unnamed formation) above the slide in our area are sheared grey shales, fan-fringe sandstone beds and a chaotic debrisflow unit (Fig. 2C). These are followed by fine-grained phyllitic claystones and siltstones, informally named the Fætta formation (Fig. 2). The highest unnamed unit in the Vuddudalen Group is a series of turbiditic greywacke-sandstone beds and intercalated phyllitic 


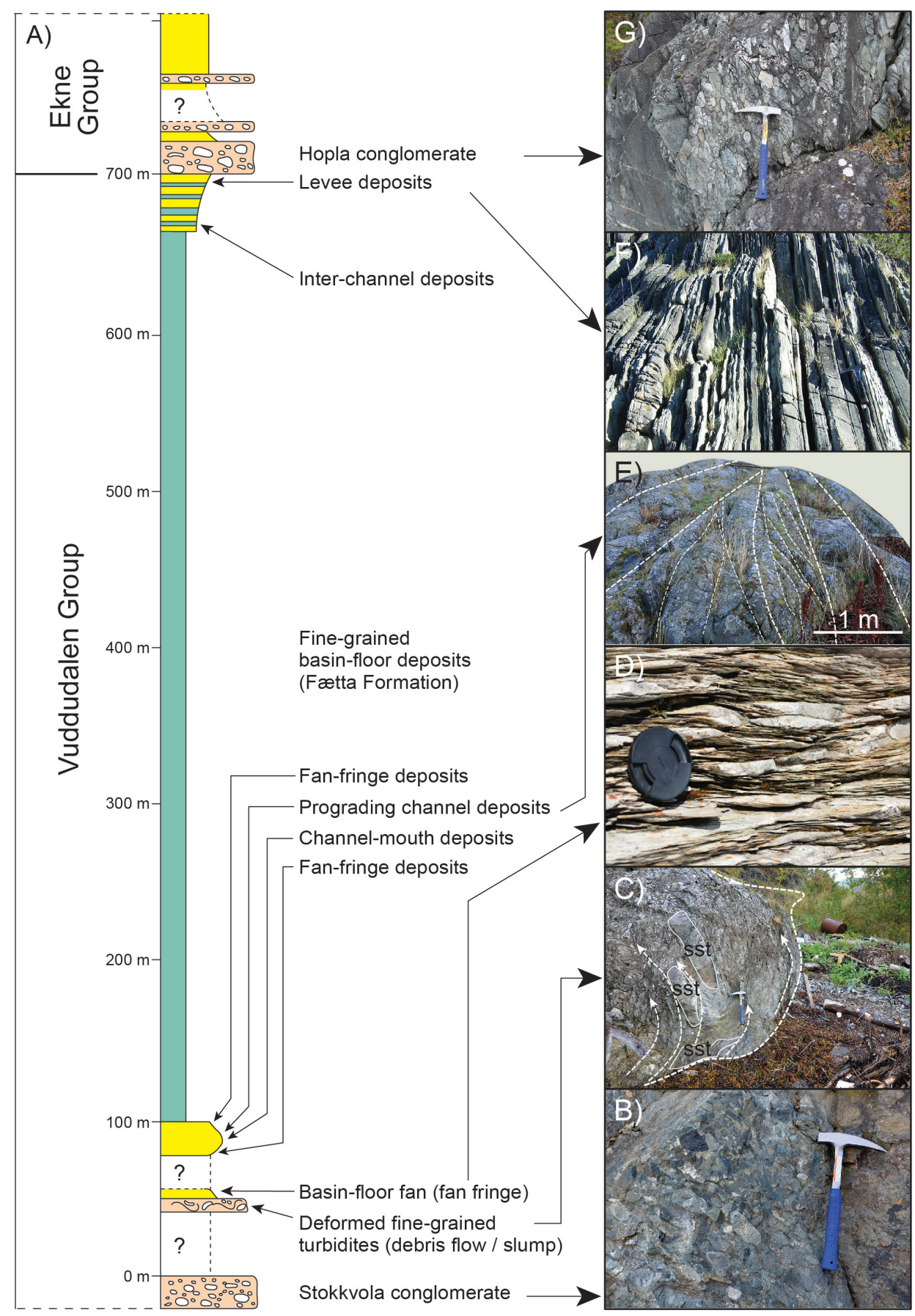

Figure 2. Logged section through the Fottenfjord profile. This is the most complete record of the lithostratigraphy in the study area. The column to the right illustrates the field expression of some of the sandstones and conglomerates. See text for discussion and Fig. 1 for location of profile.

shales, some beds of which contain the deep-marine, Nereites trace fossils (Roberts, 1969; Uchman et al., 2005). This unit occurs directly below the base of the Ekne Group, represented by the Hopla conglomerate, which is excellently exposed on the promontory Blekkpynten. About 4-5 km farther north, between Åsen and Hopla, black pyritous shales and some limestones occur directly beneath the Hopla conglomerate (Roberts, 1985). The age of the Vuddudalen Group is predominantly Ordovician, as the basal parts, including the Stokkvola formation, post-date the Tremadocian or older Forbordfjell ophiolite. Body fossils are rare in the study area and are not particularly definitive in terms of age. Gastropods, cephelopods stromatoporoids and corals of wide-ranging Mid to Late Ordovician age have been reported from the Tautra limestone (Spjeldnæs, 1985), whilst conodonts from a nearby limestone on Frosta peninsula (Tolmacheva \& Roberts, 2007) are Katian in age. Fragments of gastropods and corals also occur in the limestones in the Åsen-Hopla district. 
In the several localities marked in Fig. 1, the Hopla conglomerate contains well-rounded clasts of granite, diorite, gneiss, trondhjemite, greenstone, quartz keratophyre, chert, sandstone, siltstone, quartzite and minor gabbro, but the percentages of the different rocktypes vary from locality to locality and along strike (details are given in Pedersen, 1981). In addition, in some places, notably near Hopla and on Langøya, there are large fragments of sandstones and shales, and angular blocks of limestone between one and two metres across which are clearly short-transported. Although the Hopla conglomerate is indicated as one unit on maps at 1:50,000 scale, the formation is actually composed of twenty or more conglomerate beds separated by thin sandstone beds and phyllitic shales. Sections through the formation have been logged in detail at Hopla, Langøya, Digerberget, Gullgruva, Blekkpynten and Vikane (Fig. 3) for thickness, clast/matrix ratios, fining directions and sequence analysis (Pedersen, 1981). Due to the postdepositional tectonism and the varying appearance of conglomerates in the study area, any correlation between locations remains tentative, at best.

Above the Hopla formation, the Ekne Group comprises alternating units of shales, siltstones and grey-green turbiditic sandstone beds with several polymict conglomerate and pebbly greywacke beds. Higher up there is a series of thick-bedded, tuffaceous sandstone beds with shaly and rare tuffitic interbeds, reaching several hundred metres in thickness. The total thickness of the Ekne Group is estimated to be more than 2800 $\mathrm{m}$, based on careful calculation of dips of bedding in the upward-grading succession. Taking average rates of deposition of arenaceous sediments into account, this would suggest that the youngest sedimentary strata in the group could conceivably be of Llandovery age. Preliminary results of a provenance study (work in progress) are, in fact, indicating a Silurian age, and even possibly for the Hopla conglomerate.

\section{Facies associations/ depositional sub-environments}

The Fættenfjord profile represents the most complete record of deposition in the Lower Hovin Group from the top of the Stokkvola conglomerate, through successions of deep-water shale- and turbiditic sandstone beds and farther into the Hopla conglomerate and associated sandstone beds of the Ekne Group (Fig. 2A). The logged

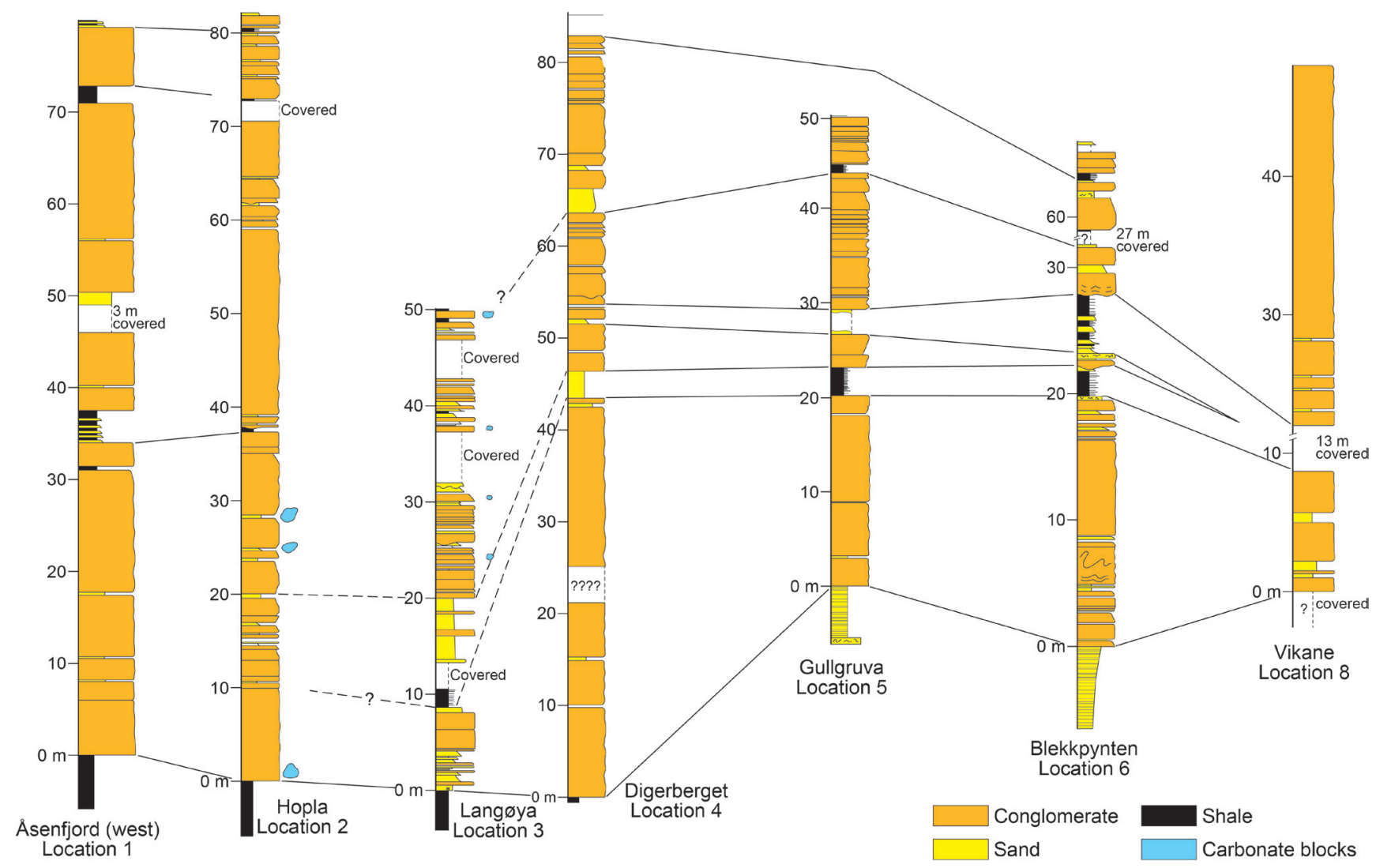

Figure 3. Logged sections of the Hopla conglomerate from selected localities in the study area. Tentative correlation datum at the base of the Hopla conglomerate. See Fig. 1 for location of logs 
section is a composite log starting at Paradisbukta (locality 7), through the Vuddudalen Group and ending at the uppermost exposures at Blekkpynten (locality 6) (Fig. 1). The subsequent discussion of basin evolution, stratigraphy, sedimentary processes and the final depositional model is largely based on detailed observations made in this area. Observations and interpretations from several other localities in the study area have provided vital information which strongly support our interpretations and help to rule out other possible scenarios.

\section{Mass-transport complex}

\section{Description}

The Stokkvola conglomerate is overlain by a shaly succession followed by a deformed unit with fragments of shale, siltstone and sandstone beds which have apparently rotated into the main body of strata (Fig. 2B, C). Neither the shale below nor the sandstones above show signs of syndepositional deformation.

\section{Interpretation}

The apparent incorporation and rotation of sandstone slabs into the finer matrix is quite similar to what is seen in mass-transport complexes worldwide and interpreted as debris flows or slumps (e.g., Martinsen et al., 2003; Odonne et al., 2011). Although outcrop with good stratigraphic control is limited to this location, we interpret the deformed unit as a debris-flow unit possibly representing the first sandy input into the basin after establishment of comparatively deep-marine conditions. It is possible that this could represent a regional masstransport complex transported in from a long distance. However, the clast material in this unit consists of finegrained sandstone beds incorporated in a mud-rich silty matrix. The fine-grained nature of both clasts and matrix suggests that these sediments originally were deposited in a lower basin-slope to basin-floor environment and thus probably represent a slumped-in unit of local origin.

\section{Distal sandstone lobes and frontal splays}

\section{Description}

Directly above the lowermost deformed unit is a succession of thin $(1-3 \mathrm{~cm})$ sandstone beds alternating with laminae of siltstone and shale, and showing relatively good lateral continuity (Fig. 2D). Primary structures are difficult to identify, and bedding generally coincides with the main schistosity, but there are many internal features which are similar to small-scale, rippledrift, cross-lamination structures. The beds also show examples of pinch-and-swell bedding of sandstone beds in fine-grained background sediment (Fig. 2D). Apart from these features, planar-parallel lamination dominates. This association is typical for distal deepmarine settings, and a distal or possibly lateral fan-fringe environment is suggested.
The thin-bedded sandstone succession is overlain by a poorly exposed succession of shale and another sandstone unit (Fig. 2E). These sandstone beds show a coarsening and fining-up trend, where the lower and upper parts have facies similar to the thin-bedded sandstone unit below. This unit shows good lateral continuity and is traceable for several hundred metres along strike. Within the middle and coarser part of the unit, the individual sandstone beds thin and thicken laterally (Fig. 2E). Beds attain a maximum thickness of 1 $\mathrm{m}$ and pinch out to just a few centimetres laterally. Within the lenses there are imbricated beds suggesting lateral accretion in smaller channel features (Fig. 2E). There is little or no shale separating the individual sandstone beds and sand-on-sand is the rule rather than the exception. Internal sedimentary structures are not evident, giving the beds a massive structureless appearance (Fig. 2E).

\section{Interpretation}

The pinch-and-swell bedding of sandstones in finegrained background sediment and planar-parallel lamination is an association typical for distal deepmarine settings. This would indicate that we are dealing with either a distal or quite possibly a lateral fan-fringe environment. The laterally continuous sandstone beds show coarsening and fining-up trends. These sandstones beds may represent a slightly more proximal part of the deep-water fan system. The lack of sedimentary structures makes it difficult to see if these sandstone lenses represent erosive features later filled by sediments or 'depositional channels' representing sandy 'fingers' spreading out from an up-dip source.

The lenses and lateral accretion surfaces are suggestive of deposition in a channel in a deep-water fan setting, possibly related to a channel-mouth environment. Because of the close association with distal, basin-floor, fan environments below and above, we interpret this unit as a basinward progradation or lateral shift of a sandy basin-floor fan relative to the underlying beds.

\section{Background sedimentation}

\section{Description}

Successions of shale are present between sandstone units and represent the background sedimentation in the basin. The shales are generally dark grey, slightly phyllitic and commonly contain small cubes of pyrite. The dark colour and the presence of pyrite are probably due to anoxic conditions in the deeper parts of the basin. Although dominantly fine grained, the shaly intervals contain an alternation between beds of clay and sand in variable amounts throughout the section from 0 to 700 metres (Fig. 2A). These sandstone beds have been divided into eight classes based on the identification of diverse sedimentary structures and the development of graded bedding (Table 1). 
Table 1. Schematic illustration of the sandstone classes as identified in the study area.

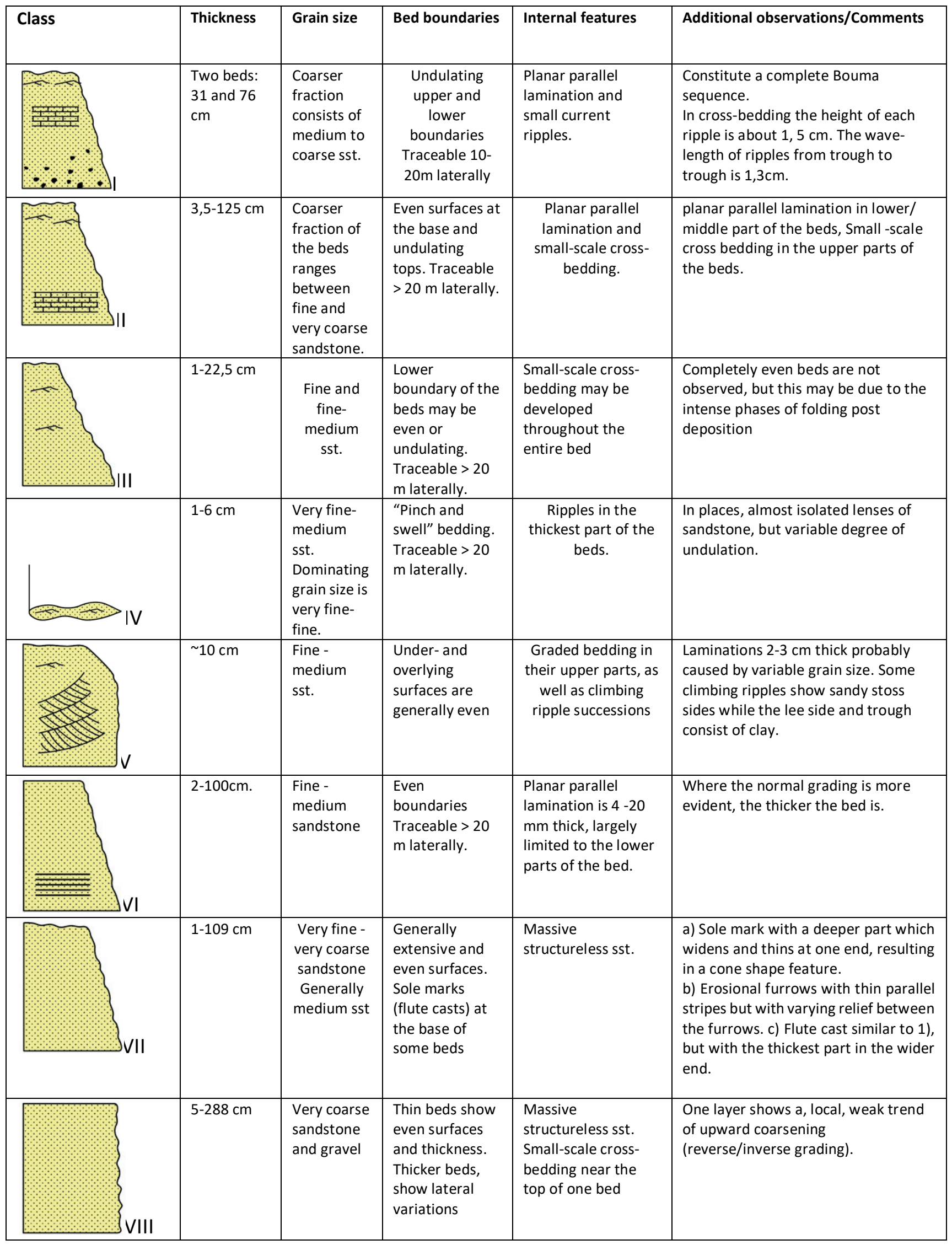




\section{Interpretation}

The trace fossils identified are found within thin-bedded turbidites and all belong to the Nereites ichnofacies which represents an opportunistic style of colonisation of the seabed by organisms adapted to fluctuations in food supply introduced by turbidity currents (Bromley, 1996). The eight sandstone classes within the overall fine-grained interval suggest that the turbidite current activity never really shut down totally in the basin. Bottom conditions were thus probably oxygenated in certain areas or in the entire basin from time to time (e.g., Torske, 1965; Roberts, 1969, 1984; Uchman et al., 2005). The alternation between sand and clay probably reflects an episodic supply of sediments to the basin, either due to sediment shut down or avulsion of feeder systems up-dip.

\section{Channels}

\section{Description}

Successions of sandstone beds typically occur below major conglomerate units and appear as 4-5, laterally accreting bodies of sandstone beds (Fig. 4). The lower boundary of any one sandstone bed shows a sharp and erosive contact with underlying shales and to some degree also with adjoining sand bodies. The sandstone beds constitute larger units that stack and amalgamate horizontally and to some degree also vertically to form a succession of sand bodies. Individual sandstone beds in successions defined by horizontal boundaries at their top and base display a series of inclined surfaces (Fig. $4 \mathrm{~A}$ ). The inclined surfaces are not following the structural grain and appear as primary bedding surfaces and thereby suggest lateral accretion during deposition (Fig. 4A). It is generally difficult to identify any grain-size separation within and between accreting surfaces, but in a few places coarser-grained sandstone or even conglomeratic sediments are found near the base of individual sandstone beds (Fig. 4B). Moreover, distinctly deformed units within otherwise well-stratified beds appear at certain positions within the sandstone successions (Fig. 4C). The deformed units are composed of the same material as the adjoining sandstone beds and parts of the primary bedding are preserved within these units. The appearance of the deformed units thus probably reflects a local origin and short distance of transport.

\section{Interpretation}

The unconformable lower boundary and overall geometry points to a channellised deposit incising into the finer-grained substratum. The presence of coarsegrained deposits at the base of sandstone beds probably represents lag deposits indicative of sediment bypass and throughgoing turbidity currents. The horizontal and vertical stacking of sandstone beds strongly suggests lateral migration of sandy channel belts in a deep-marine environment (e.g., Beaboef, 2004, Mayall et al., 2006; Wynn et al., 2007). The outcrops do not allow for plan view of the sandstone geometries, but the associations have a strong resemblance to sinuous channel systems (e.g., Janocko et al., 2013; Li et al., 2016) (Fig. 4D).

\section{Levees/overbank}

(thin-bedded sandstone successions)

\section{Description}

Stacked successions of thin-bedded turbidite beds are found in several locations within the study area, and most notably on the Blekkpynten location (Figs. 2F, 5A). These appear as alternations of thin-bedded turbidites and shale layers (Figs. 2F, 5A). The sandy deposits thin out from a few decimetres (maximum $50 \mathrm{~cm}$ ) to a few centimetres over a lateral distance of $100 \mathrm{~m}$. Over the same distance the sandstone beds also become finer grained and grade from medium-grained sandstone to a very fine-grained sandstone and siltstone.

A variety of sedimentary structures are observed within this succession. Most common are planar lamination ripples and climbing ripple successions and one bed even displays a complete Bouma sequence (Fig. 5A). Examples of penecontemporaneous deformation of individual sandstone beds also occur within this succession (Fig. 5B), where both the overlying and the underlying beds seem to be virtually unaffected by this slump-type deformation. The deformed beds display contortions and unidirectional folds of the sandstone and shale, which in places are also broken up and rotated, suggesting that the beds must have been consolidated to some degree at the moment of deformation (Fig. 5A, B). The massive sandstone of the overlying bed appears to fill in the sea bottom relief caused by the slump-deformation process. It is thus likely that this is a local feature, and most probably a cohesive slump or debris flow released on an inclined surface of a slope or channel margin/levee. Evidence for current activity is given by the presence of the above-mentioned sedimentary structures. In addition, there are also some nice examples of flute casts at the bases of some beds that document current activity during deposition (Fig. 5). In the more fine-grained parts of the succession there are beds containing the deep-marine, Nereites ichnofacies (Roberts, 1969; Uchman et al., 2005) (Fig. 5D). Small disconformities within the otherwise more or less planar-bedded sandstone succession occur as local erosive features (Fig. 5A). These features display a sharp erosive boundary and are filled with well stratified thin-bedded sandstone (Fig. 6A). Apart from these subordinate erosional features the succession is dominated by planar-stratified beds, quite a few of them exposing successions of climbing ripples (Fig. 6B) which also display signs of synsedimentary deformation within individual beds (Fig. 5B).

\section{Interpretation}

The abundant evidence of current activity points to a close association with a sediment conduit or turbidite channel on the continental/basin slope. Both the 

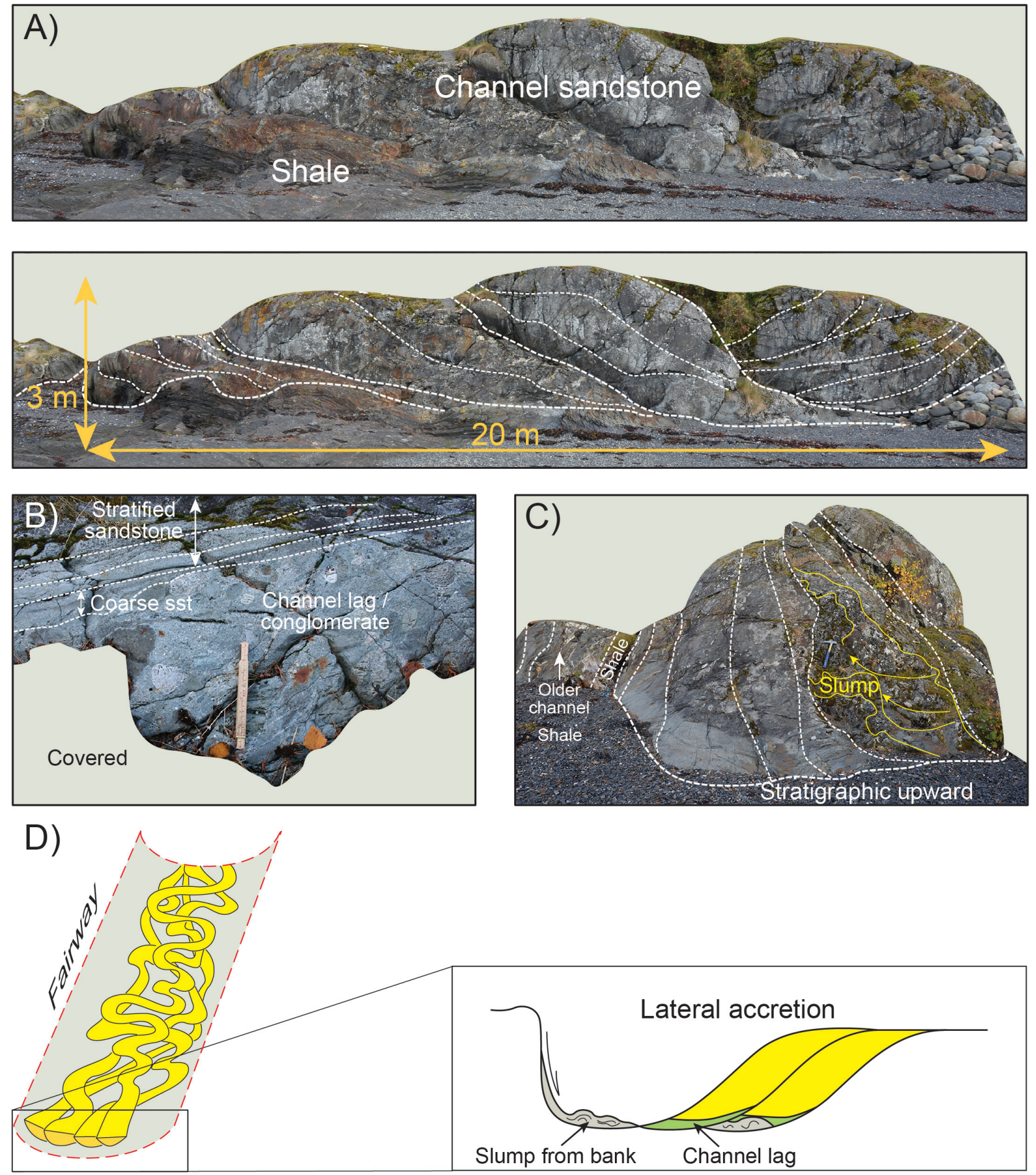

Figure 4. Laterally accreting bodies of sandstone (A) in a shaly background environment at the Lofjorden locality. (B) Coarse-grained channel lag deposits with a fining-up trend via coarse sand into medium to fine sandstone. (C) Deformed sandstone embedded between well stratified sandstone beds. (D) Simplistic model for the occurrence of sedimentary features in laterally accreting sandstone units in sinuous channels. See Fig. 1 for location.

stratigraphic and the lithological thinning of sandstone beds seen in these facies are features characteristic of levees bounding deep-water channel systems (e.g., Janocko et al., 2013). Whilst the coarser-grained part of the turbidity current is kept within the channel, sand and clay particles will spill over channel margins as very thin beds or laminae and thin out both laterally and texturally away from the channel. The climbing ripple successions result from sediment fallout and net deposition and suggest that sediments contained in channel overflows were deposited relatively rapidly after leaving the main conduit (Fig. 6). The overflow from channels is most 

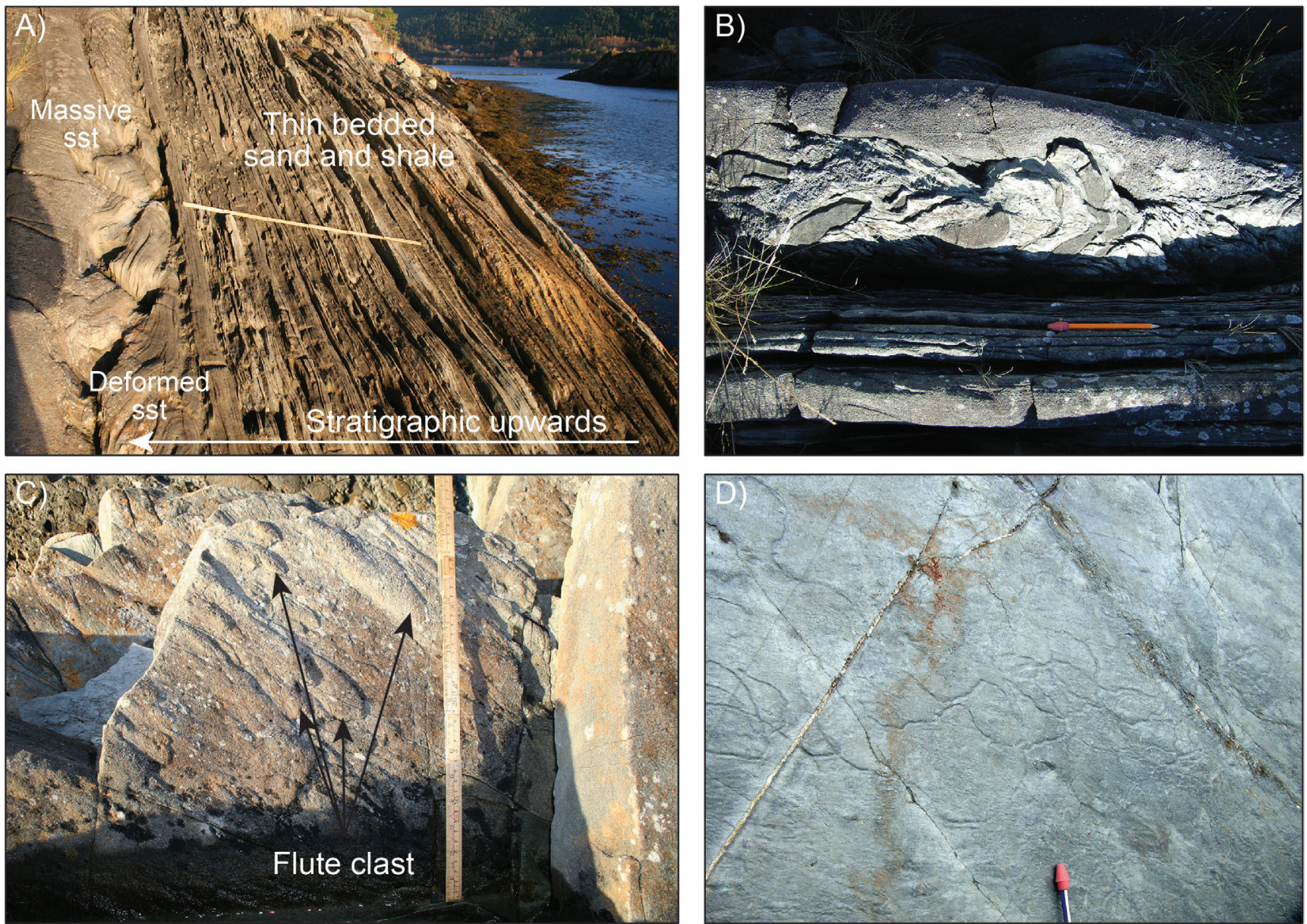

Figure 5. Features of the sandstone succession at the Blekkpynten locality in the Foettenfjord profile. (A) Alternating thin-bedded turbidite sandstone and shale. Sandstone beds increase in thickness and content of sand upwards, and deformed sandstones with slump folds are found beneath thicker beds. (B) Detail of (A) displaying the undisturbed lower surface of the deformed sandstone and the well-structured sandstone above, filling in the relief on top of the inferred mass-movement deposit. (C) Flute casts on the bottom surface of a sandstone bed. (D) Trace fossils of the Nereites (Megagrapton) ichnofacies on the bottom surface of a sandstone bed found along the track leading to the Blekkpynten location.
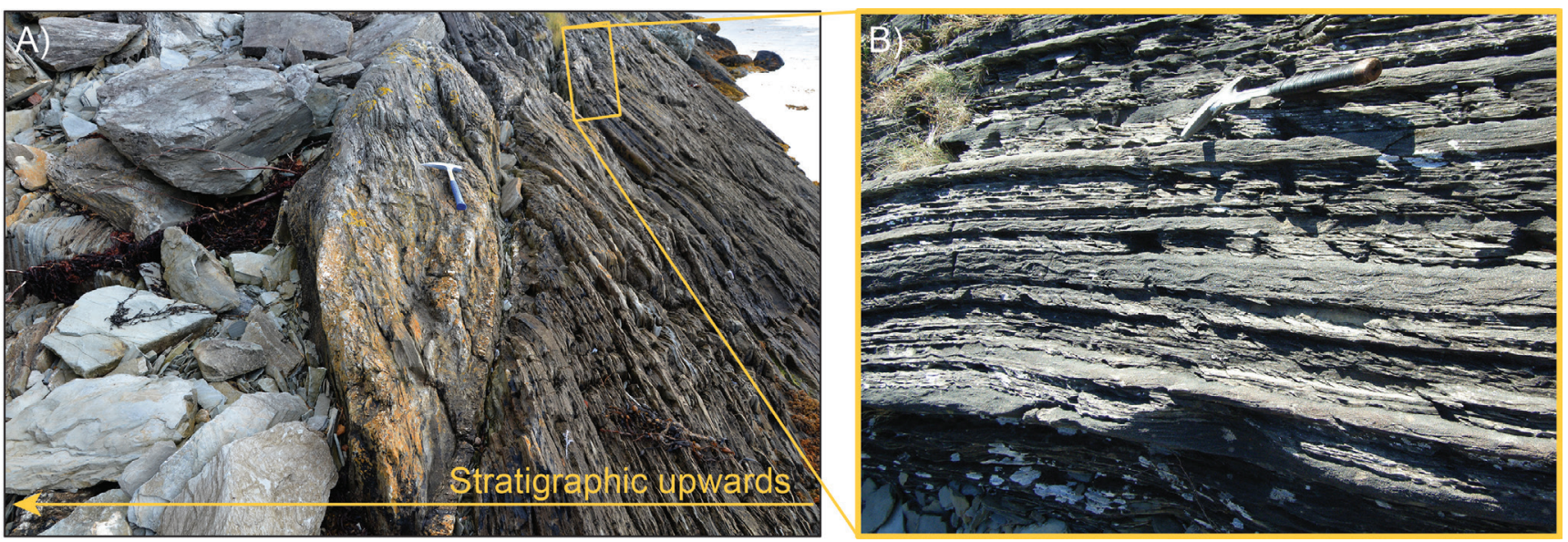

Figure 6. (A) Crevasse splay channel in inferred levee deposit at the Blekkpynten location. Stratigraphic up is towards the left in the photo. See text for discussion. (B) Enlarged section of (A) showing thin-bedded turbidites with climbing ripples. Note also small-scale deformation structures in some of the beds.

likely not a continuous process and some consolidation of beds may occur between each event. This may account for the deformation of inferred semi-consolidated beds on levee slopes. From time to time the levee will break and create crevasse channels and eventually splays on the levee surface (Lopez, 2001). Channel levee breaks may thus be a viable explanation to the erosive features within the thin-bedded sandstone succession. 


\section{Conglomerate successions}

\section{Description}

The Hopla conglomerate contains pebbles and cobbles of a variety of rock types, mainly quartzite, grey granite, fine-grained gneiss, porphyritic andesitic greenstone and green-grey sandstone, with subordinate felsic volcanites and gabbro (Törnebohm, 1896; Vogt, 1945). A principal feature of the Hopla conglomerate is the well-rounded clast material (Fig. 7A). Another characteristic feature of the conglomerate successions is the alternation between clast-supported and matrix-supported conglomerates (Fig. 7A, Table 2). Notably the conglomerate beds show trends of coarsening up, fining up and coarsening-fining up-, as well as massive bedding (Table 2).
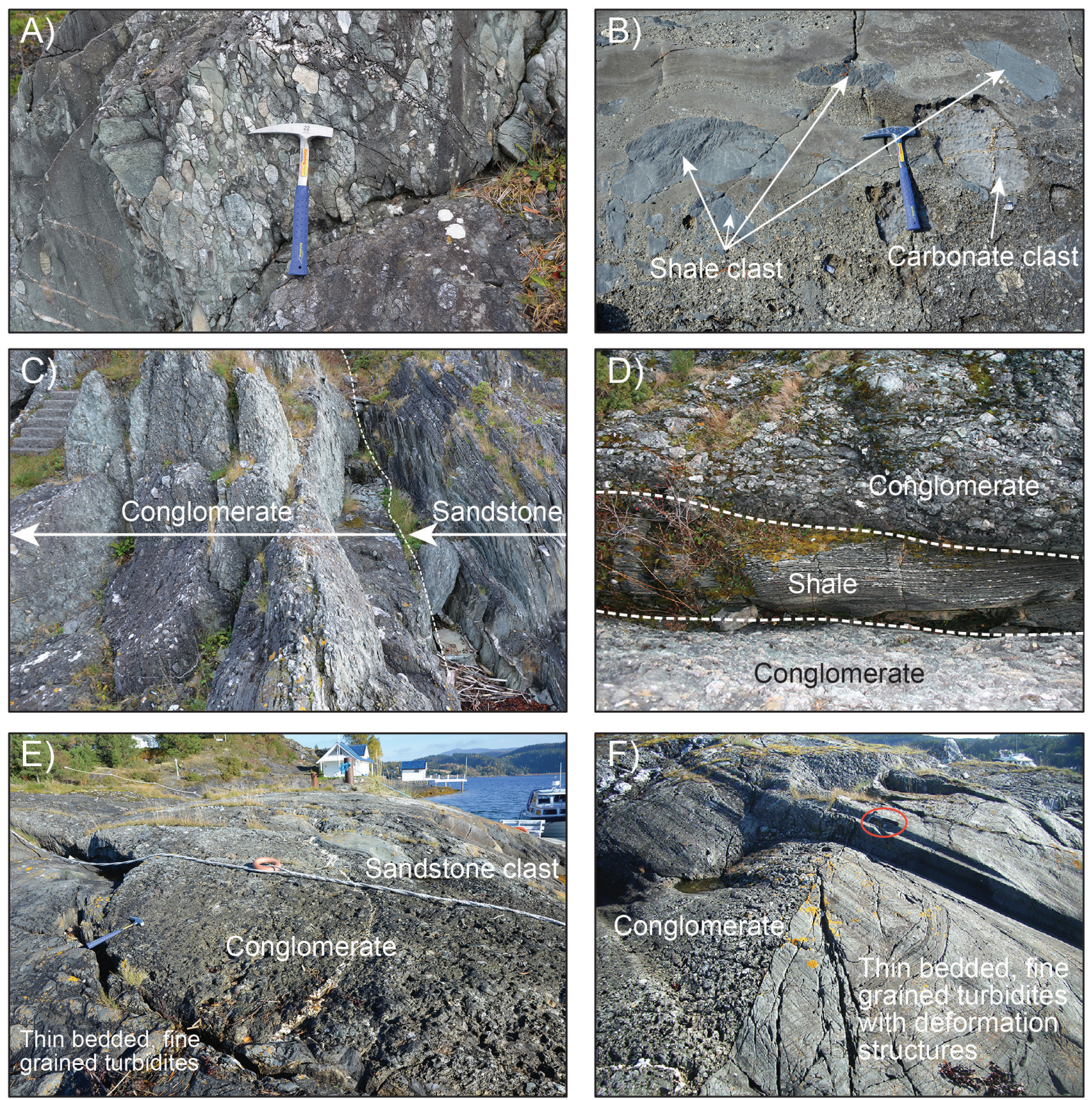

Figure 7. Conglomerates in the study area. (A) The Hopla conglomerate at Blekkpynten in the Fottenfjord succession. Note the well-rounded conglomerate clasts and the alternation between clast-supported and matrix-supported conglomerate. (B) Shale clasts and an angular clast of limestone embedded in coarse-grained immature sandstone beds in alternation with structured sandstones from the Langøya location in Lofjorden. (C) Sandstone in alternation with fine-grained thin-bedded sediments showing a sharp transition towards the overlying Hopla conglomerate. (D) Example of shale separating conglomerate successions at the Gullgruva location. (E) Conglomerate succession deposited directly on underlying fine-grained/shaly turbidite deposits, Location Langøya. Note the folding and shearing of beds below the conglomerate and an angular sandstone clast (1 m across) 'floating' on top of the conglomerate unit. (F) Conglomerate succession deposited directly on underlying fine-grained/shaly turbidite deposits, at Langøya. Note the folding and shearing of beds below the conglomerate. See Fig. 1 for location of photos. 
Table 2. Summary table of conglomerates in the study area. Both the matrix-supported and the clast-supported conglomerates can be separated into four classes: massive, inverse graded, inverse to normal graded and normal graded. Thickness ranges, average thicknesses and mean clast size are indicated. Average measurements were carried out on representative beds (those that occur most commonly). Outliers are not included in the calculations.

\begin{tabular}{|c|c|c|c|c|c|c|}
\hline Class & $\begin{array}{c}\text { Relative } \\
\text { abundance \% }\end{array}$ & $\begin{array}{c}\text { Thickness } \\
\text { Range/average } \\
\text { cm }\end{array}$ & $\begin{array}{l}\text { Mean } \\
\text { Particle Size } \\
\text { cm }\end{array}$ & Bed boundaries & $\begin{array}{l}\text { Internal } \\
\text { features }\end{array}$ & $\begin{array}{l}\text { Additional } \\
\text { observations }\end{array}$ \\
\hline \multicolumn{7}{|c|}{ Matrix supported conglomerates $68,5 \%$ of total conglomerates in study area } \\
\hline 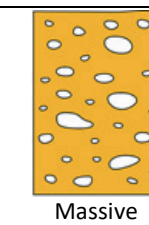 & 38,3 & $\begin{array}{c}10.0-211.0 \\
\text { Average: } 70\end{array}$ & $\begin{array}{c}2.5-29.0 \\
\text { Mean: } 10.3\end{array}$ & Conformable & $\begin{array}{c}\text { Random } \\
\text { distribution of } \\
\text { clasts of all sizes. }\end{array}$ & $\begin{array}{l}\text { One location, show } \\
\text { clasts of very fine- } \\
\text { grained sandstone in } \\
\text { alternation with } \\
\text { millimetre-thick } \\
\text { laminae of clay or } \\
\text { silt. }\end{array}$ \\
\hline $\begin{array}{l}0 \\
\text { Inverse }\end{array}$ & 10,4 & $\begin{array}{l}7.0-181.0 \\
\text { Average: } 55.8\end{array}$ & $\begin{array}{c}7.5-28.5 \\
\text { Mean: } 15.4\end{array}$ & $\begin{array}{c}\text { Erosive on sst. } \\
\text { Sharp on conglomerate }\end{array}$ & $\begin{array}{l}\text { Increasing matrix } \\
\text { content and clast } \\
\text { size upwards }\end{array}$ & $\begin{array}{l}\text { Constant grain size in } \\
\text { matrix }\end{array}$ \\
\hline 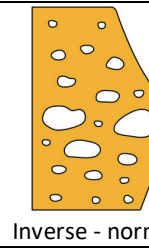 & 17,4 & $\begin{array}{c}23.0-212.0 \\
\text { Average: } 77.5\end{array}$ & $\begin{array}{c}6.0-58.0 \\
\text { Mean: } 20.3 \mathrm{~cm}\end{array}$ & Mostly erosive & $\begin{array}{l}\text { Less matrix in } \\
\text { inverse part of } \\
\text { bed }\end{array}$ & $\begin{array}{l}\text { In places, the inverse } \\
\text { grading first appears } \\
\text { as ungraded beds } \\
\text { with only a few } \\
\text { larger clasts } \\
\text { concentrated in } \\
\text { distinct layers }\end{array}$ \\
\hline$\frac{10}{0}$ & 33,9 & $\begin{array}{c}7.0-190.0 \\
\text { Average: } 46.4\end{array}$ & $\begin{array}{c}2.5-30.0 \\
\text { Mean: } 13.8\end{array}$ & $\begin{array}{l}\text { Erosional base. } \\
\text { Gradational top }\end{array}$ & $\begin{array}{l}\text { Upward increase } \\
\text { in matrix content }\end{array}$ & $\begin{array}{l}\text { In some rare cases } \\
\text { this matrix shows a } \\
\text { gradual transition } \\
\text { into overlying } \\
\text { sandstone beds. }\end{array}$ \\
\hline \multicolumn{7}{|c|}{ Clast supported conglomerates $31,5 \%$ of total conglomerates in study area } \\
\hline$\frac{8886}{288}$ & 30,2 & $\begin{array}{l}21.0-143.0 \\
\text { Average: } 66,7\end{array}$ & $\begin{array}{l}3,0-41,0 \\
\text { Mean: } 12.8\end{array}$ & Even and concordant & $\begin{array}{c}\text { Random } \\
\text { distribution of } \\
\text { clasts of all sizes. }\end{array}$ & $\begin{array}{l}\text { Beds up to } 175 \mathrm{~cm} \\
\text { observed; likely } \\
\text { amalgamation }\end{array}$ \\
\hline 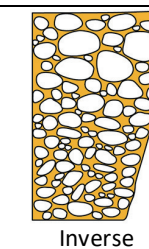 & 15,1 & $\begin{array}{c}\text { 20.0 - } 215.0 \\
\text { Average: } 117.0\end{array}$ & $\begin{array}{c}\text { 6,5 - } 33,0 \\
\text { Mean: } 20,9\end{array}$ & $\begin{array}{l}\text { Sharp, but no obvious } \\
\text { erosion }\end{array}$ & $\begin{array}{l}\text { Matrix increase } \\
10-15 \% \text { upwards: } \\
\text { the opposite } \\
\text { occurs in one bed }\end{array}$ & \\
\hline 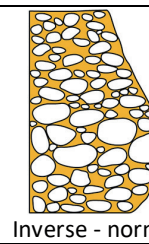 & 13,2 & $\begin{array}{c}24-128 \\
\text { Average: } 52.3\end{array}$ & $\begin{array}{c}9.0-30,0 \\
\text { Mean: } 19.1\end{array}$ & $\begin{array}{l}\text { Erosive channel- } \\
\text { geometry or planar } \\
\text { and evenly levelled } \\
\text { surfaces }\end{array}$ & $\begin{array}{l}\text { inversely graded } \\
\text { part } 17.2-37.3 \% \\
\text { of total bed } \\
\text { thickness }\end{array}$ & $\begin{array}{l}\text { One bed } 360 \mathrm{~cm} \\
\text { thick, may be a result } \\
\text { of amalgamation }\end{array}$ \\
\hline 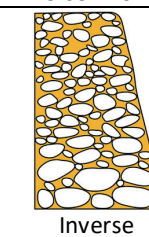 & 41,5 & $\begin{array}{c}\text { 15-180 } \\
\text { Average: } 69\end{array}$ & $\begin{array}{c}5,5-22,5 \\
\text { Mean } 13.4\end{array}$ & Even, non-erosive & $\begin{array}{l}\text { General increase } \\
\text { in matrix } \\
\text { upwards. } 40 \% \mathrm{r} \\
\text { reduction occurs }\end{array}$ & $\begin{array}{l}\text { Matrix grain size } \\
\text { overall constant, } \\
\text { fine-medium } \\
\text { sandstone. }\end{array}$ \\
\hline
\end{tabular}


In addition, there are clasts of shale up to a metre in length, as well as angular blocks of sandstone and limestone, up to two metres across, which are clearly short-transported and derived from subjacent depositional units (Fig. 7E). The conglomerate also contains intercalated beds of immature sandstone, some of which are continuous within any one outcrop (Figs. $7 \mathrm{~A}, 8)$. Some beds within these sandstone intercalations show large-scale cross-bedding with set thicknesses of up to $50 \mathrm{~cm}$ (Fig. 8C, D, F). These cross-bed sets extend laterally over several metres with variable degrees of erosion at their bases. They also show a basal section of thinly bedded strata displaying sets of climbing-ripple laminations, succeeded by more massive sandstone beds with discrete accretion surfaces building a dune or bar form (Fig. 8B, D). Notably, these dunes seem to have an element of aggradation which suggests that they are 'climbing dunes' in the sense of Mutti et al. (1996). Near the top of the same bar form, the thin-bedded strata display sets of climbing ripples (Fig. 8B). The massive sandstone beds are fine to medium grained, whereas the climbing-ripple successions consist of fine- to very finegrained sandstone.

The lower boundary of the conglomerates commonly represents an unconformity and shows clear evidence of erosion into the underlying sandstone- or claystone beds. There are also several erosional features within the conglomerates and between thicker successions of conglomerates. Smaller and larger erosional features
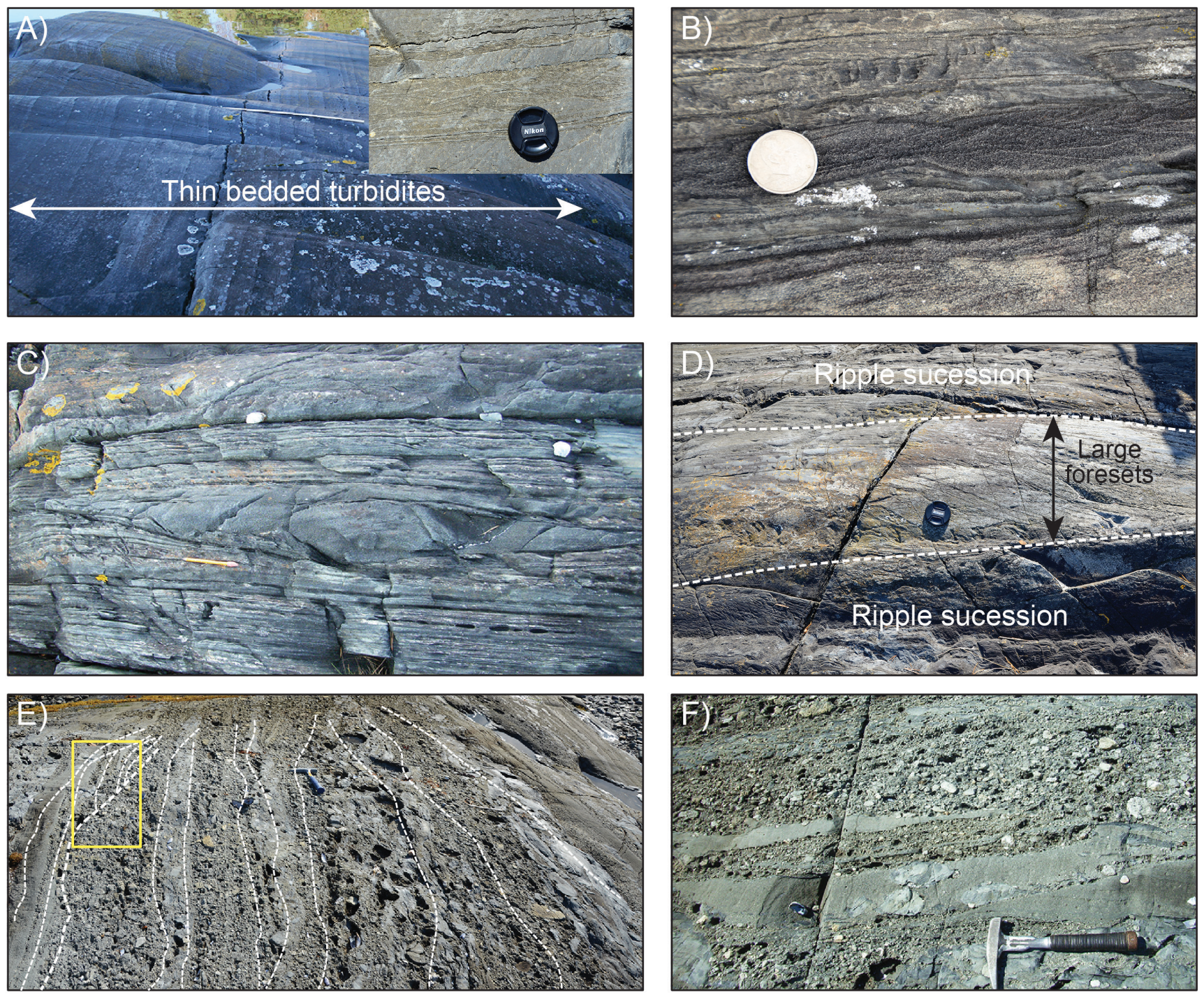

Figure 8. (A) Sandstone dominated by evenly spaced, thin-bedded turbidites. Inserted photo is a close up of the same outcrop and shows an example of the climbing-ripple succession within the unit, Location Langøya. (B) Climbing ripples in sandy beds between conglomerate beds, Location Blekkpynten. (C) Coarser-grained channel with foresets within sandy section between conglomerates (pencil for scale), Location Blekkpynten. (D) Larger cross beds or foresets with climbing-ripple succession below and above, Location Langøya. (E) Alternating sandstone and conglomerate succession at Langøya, Lofjorden. Stratigraphic upwards is towards the right in the photo. (F) Enlarged section (red square in E) illustrating bed boundaries, scouring and fill relations between sandstones and conglomerates. 


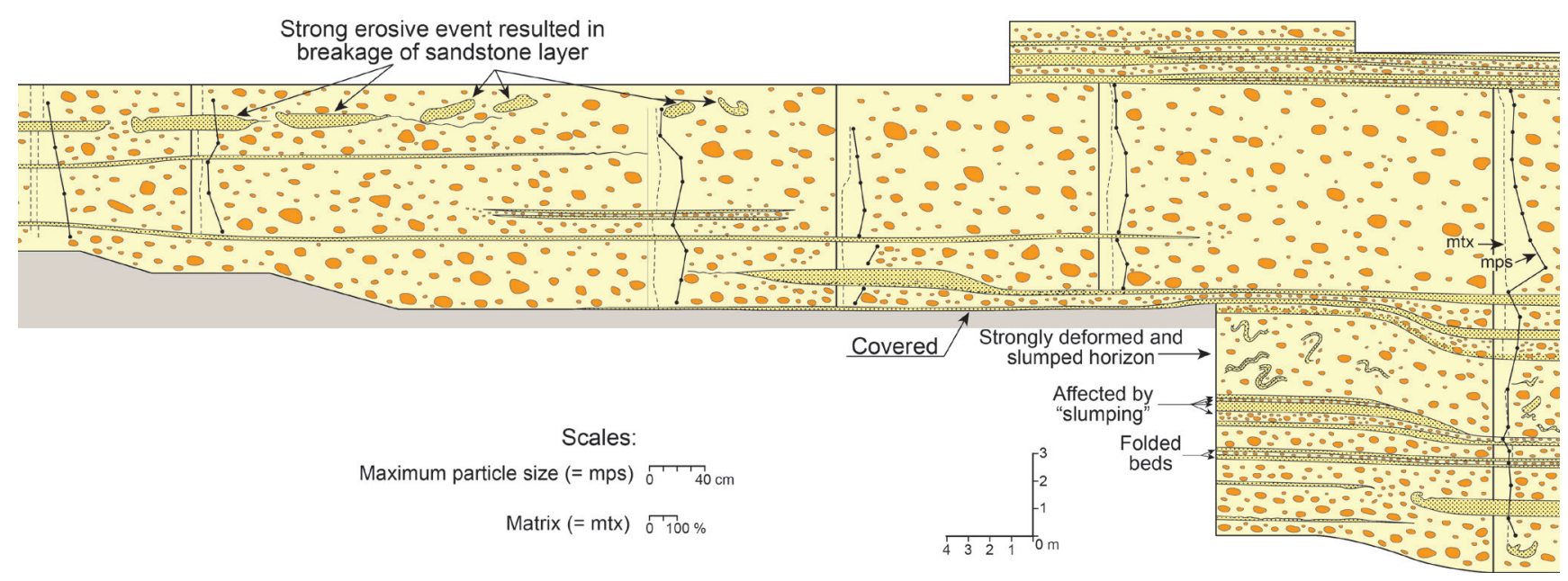

Figure 9. Vertical logs with horizontal correlations at the Blekkpynten location. Note that sands may appear as lenses that wedge out within a short distance. Deformation structures result from both synsedimentary and post-sedimentary processes (See Fig. 1 for location and text for discussion).

at the base of the conglomerates and within the conglomerate successions are filled in with conglomerate beds of variable thickness and extent. Many of these beds show an even thickness over $2-4 \mathrm{~m}$ and then wedge out rapidly to zero within $0.5 \mathrm{~m}$ (Fig. 9). The sediments underlying conglomerates commonly display syn-depositional deformation structures and examples of the underlying deposits having been detached and incorporated into the conglomerates as large angular clasts (Fig. 7).

\section{Interpretation}

The lower boundaries of both sandstone and conglomerate beds appear to erode into the underlying shale successions which commonly contain the deepmarine Nereites ichnofacies (Fig. 5). This implies that even though the conglomerates are transported and possibly also deposited in a channellised environment, the overall setting must have been deep marine and close to the basin floor.

The climbing ripples are indicative of a waning flow and net deposition, whereas the massive, slightly coarsergrained sandstone beds are suggestive of waxing flow and an element of bypass. Building a larger bar or dune form in deep-marine settings will generally occur gradually over some time and will require a sustained flow lasting for hours or days, or even longer (Mutti et al., 1996; Zavala et al., 2011).

The conglomerates may be regarded as hyperconcentrated gravity flows (sensu Mutti, 1992) that experienced several phases of flow transition on their way to the basin sink. The variable fining up, coarsening up, coarsening up-fining up and massive trends for the conglomerate beds suggest highly variable current conditions. If the conglomerates were triggered by one specific event, and initially move en masse down the slope, they are assumed to have the character of debris flows in the upper reaches of the fairway. Farther downslope they will naturally incorporate more water, and with that lose the capability of carrying larger clasts. The conglomerate material will be transported along the base of the fairway and the kinetic sieving and/or dispersive pressure of the throughgoing current will thus result in inverse grading. When the gradient flattens out, the inversely graded conglomerates will be deposited relatively quickly, while the remaining part of the current will bypass. The currents will then deposit inverse/normal-graded beds, and normally graded to massive beds will develop farther downslope. It is thus still possible that the sandy successions and thin-bedded turbidites beneath conglomerates may represent parts of the same mass flow, but they must then be explained as lateral or distal equivalents of the massive, coarsegrained input. Whereas the sandy units are local features, most of the basin fill comprises thin-bedded fine-grained sandstones within mainly shaly intervals.

\section{Upper slope/shelfal sandstones}

\section{Description}

Thick successions of very fine to fine-grained greenish sandstone beds and shales are found in the western parts of the study area (Fig. 10). These facies comprise thin-bedded graded sandstone beds with very few sedimentary structures preserved. Ripples and crossbedding structures are preserved in a few places, but it is often quite difficult to distinguish primary planar structures from the regional schistosity in parts of the study area (Fig. 10). However, a repetitive pattern of thinbedded normal-graded sandstone beds characterises the unit (Fig. 10). Larger bedforms such as lenticular beds with a size and geometries similar to hummocky cross-bedding do occur (Fig. 10). Larger erosive features 

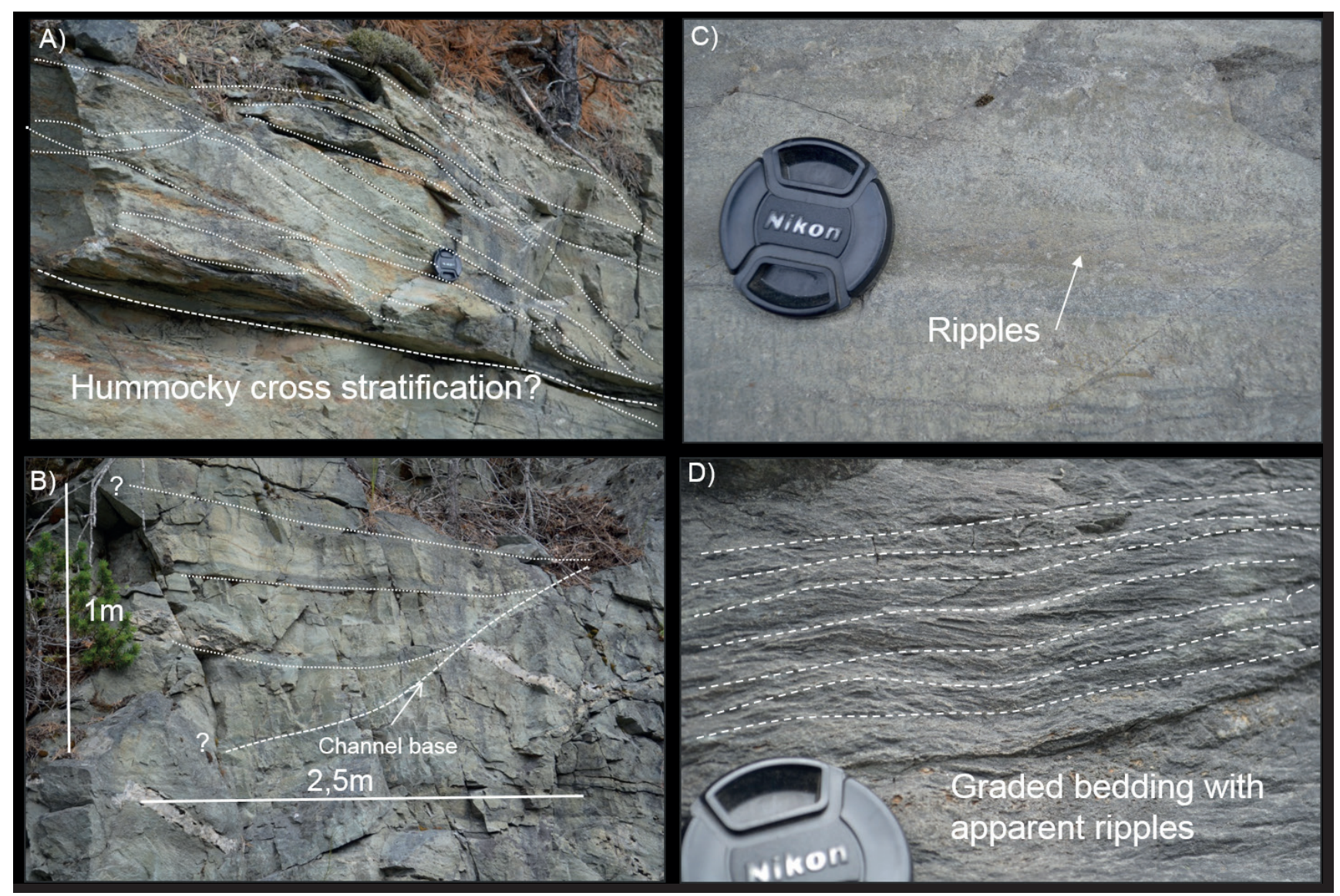

Figure 10. (A) Inclined surfaces in sandstone succession interpreted to represent hummocky cross stratification or large-crossbedding. (B) Channel geometry within thin-bedded turbidites in the western and inferred most proximal part of the study area. (C) Ripple structures and faint graded bedding. (D) Apparent (false) ripple structures between bedding due to schistosity induced by later tectonic phases.

occur in the form of a channel geometry incising into the underlying strata. The infill of these channel features is little different from the underlying lithology (Fig. 10).

\section{Interpretation}

Thick successions of normal-graded, thin-bedded, finegrained sandstone point to a relatively high sediment supply with repeated input of fine-grained sediments. The pale greenish colour of the sediment points to an oxygenated depositional environment, quite unlike the dark-coloured shale successions in the inferred deep-marine parts of the basin. Considering a very sandy sediment with a narrow grain-size distribution, deposition offset, but not too far from a main feeder system is suggested. The exact location of the sediment in a source to sink perspective is difficult to pinpoint due to the quality of the outcrop, but the hummocky crossbedding points to a shallow-marine shelf environment. The channel feature is not diagnostic in itself, but the lack of coarse-grained lag suggests low gradients with little sediment bypass before the infill of sediments that are quite similar to the substrate. Based on the observations and overall appearance, we interpret these thin-bedded sandstone and shale beds to represent either shelf or upper slope deposits.

\section{Discussion}

The post-depositional erosion of the sedimentary succession and subsequent Scandian deformation inhibits a full source to sink analysis of the basin. Whereas the deep-water part of the depositional system is well preserved in the study area, only a few examples of inferred hummocky cross-stratification in close association with a possible channel feature are found in the western part of the area (Fig. 10). Although hummocky cross-bedding has traditionally been interpreted to result from storm wave action on the continental shelf, it has been found to originate from several different processes and can easily fit into a model involving high sedimentation rates and unidirectional flows (Southard et al., 1990; Mutti et al., 2007; Quin, 2011). The interpretation remains speculative, but the repeated pattern of graded, thin-bedded sandstones, hummocky cross-stratification and channellisation may represent an integral part of the turbidity system.

Evident from the trace fossil assemblage, facies associations and sedimentary structures, the sandstone channels and levee facies were deposited in a deepmarine slope environment. Moreover, these facies 
associations are commonly found beneath the conglomerate successions and it is plausible that they occupied the same sedimentary fairway on the slope. The lateral migration of sandstone facies within and among inferred channel geometries suggests some degree of sinuosity of the channel systems. Sinuous and laterally accreting channels tend to form as a result of sediment accumulation at inner and outer channel bends, unlike fluvial systems that consistently erode at outer bends and deposit sediments on inner channel bends (Posamentier \& Kolla, 2003; Kane et al., 2008; Janocko et al., 2013). The variable degree of deposition and bypass in submarine systems allows for more stable channel geometries than in the fluvial counterpart. There is, however, general consensus that the axial part of the channel will be a zone dominated by coarse-grained sediment bypass lags (Fig. 4B), and that lateral migration will still occur (e.g., Abreu et al., 2003; Posamentier \& Kolla, 2003). Because of the asymmetry in channel cross-section created by the variable flows, instability and slumping is likely to occur at channel margins when the deepest part of the channel is shifted towards either of the channel margins. This accounts for the deformed beds seen in the channel successions (Fig. 4C). Since the turbidity current is driven by gravity, most sediment movement is naturally downslope. However, the current also interacts with the flow separation along channel margins and local flow cells will develop, similar to eddies and back-logs in fluvial systems. This flow pattern is likely to contribute to lateral movement of sediments and the creation of bar forms and accretion surfaces in the channels. The few observations of channels in the study area do not justify our proposing a detailed model for channel evolution, but nicely documents channellised flows and allows for a general model to explain the observed stacking pattern (Fig. 4D).

Channellisation within and at the base of conglomerate successions suggests that conglomerates were transported into the basin along the same sedimentary fairways as the sandy channel deposits. Whether the sandstone and conglomerate beds represent separate events or just grain-size variations within the same event of sediment release, remains uncertain. What is readily observed is that several events of conglomerate deposition are stacked on top of each other within these fairways, and thus suggest repeated events of deposition (Figs. 7D, 8, 9). The occurrence of conglomerates in deepwater settings will, in general, be limited to channels or larger conduits on the basin slope. Such channels may attain significant dimensions and some have been recorded up to $25-30 \mathrm{~km}$ in width and $200 \mathrm{~m}$ in depth (e.g., Hickson \& Lowe, 2002). The actual distribution of conglomerates in the study area is difficult to perceive due to the complex structuring of the area. The suggested datum for correlation (Fig. 3) may therefore represent several conglomerate-filled channels, offset in both time and space.
The interchangeable sandstone and conglomerate beds and the incorporation of coarse-grained material in the sandstone beds as well as sands within the matrixsupported conglomerates suggest that these sediment types are closely associated and parts of the same event. The sandstone beds associated with conglomerates generally show well preserved sedimentary features with relatively thick units of evenly spaced, thin-bedded turbidites dominated by rippledrift and climbing-ripple structures (Fig. 8A, B).

Sandy beds may settle out from the 'tail' of the turbidity current or possibly also from separate events of current flow. If sandstone beds are deposited as separate events, they may accumulate in proximal parts of the system. Bypassing currents will subsequently erode and entrain the channel sands and deposit these as part of the normally graded beds at the distal end of the system. In this model, winnowing of sands in the proximal parts will make it more likely to find inversely graded, clast-supported conglomerates in the upper reaches of the channel fairway, a transitional zone with relatively thin beds of inverse/normal-graded beds, and thicker, normally graded, matrix-supported conglomerates in the more distal setting. This depositional model should be regarded with some caution since even hyper-concentrated flows will vary in velocity and concentration. Consequently, individual currents will deposit proximal and distal facies at different locations, and the distal-proximal criterion for the classification of deep-marine conglomerates becomes difficult to apply.

The proximal-distal model for explaining the matrix content and bedding style may be redundant in any event, since even the slightest sinuosity of the channel will result in a lateral sorting of material (e.g., Jobe et al., 2010). The active channel will be dominated by conglomerates, while sandy material will be deposited along channel margins both as clean sandstone beds and, as a result of channel 'overflow', also as matrix between the clast material. Flow velocities will vary within a sinuous channel system, and flow separation will result in the development of lateral accretion surfaces and bar forms at channel bends (e.g., Posamentier \& Kolla, 2003; Mayall et al., 2006; Janocko et al., 2013). Flows may erode the matrix-rich deposits in fast-flowing parts of the channel and deposit its material where the flow slows down at the next channel bend. This process will result in winnowing of finer-grained material and deposition of clast-supported material along the channel thalweg. An important prerequisite for this model to work is that there is very little time between erosion and deposition, and that there is not time enough to properly incorporate all the fine-grained material in the suspension cloud of the turbidity current. In this way, clast-supported conglomerates may be deposited in the channel thalweg (or areas of fastest flow) and the matrix-supported conglomerates deposited where flows are slower. Clastsupported and matrix-supported conglomerates may 
thus occur side by side without implying a proximaldistal concept.

The abundant occurrence of carbonate clasts, some of significant size, provides evidence for periods of carbonate reef growth along the basin margin. The presence of carbonate reefs suggests limited siliciclastic sediment supply to the shelf for long periods of time. This implies equally long periods of accumulation, storage and reworking of coarser-grained sediments in near-shore and onshore areas. The initial rounding of clasts may have occurred in a fluvial environment, but the presence of well-rounded carbonate clasts suggests that some of the abrasion of clasts results from reworking by marine processes in the littoral zone. The energy needed to overcome the barrier represented by the 'energy littoral fence' set up by the longshore currents is quite considerable (sensu Mazullo \& Erlich, 1980). In reality, only flood-generated, supersaturated flows have sufficient energy to escape marine diffusion processes and transport coarse-grained material away from the shore zone (Allen, 1970; Mutti et al., 1996). Although reworking of carbonate material is evident, there are also examples of large, angular blocks or clasts of carbonate, sandstone and shale that must be locally derived and transported over only short distances.

The coarse-grained sediments stored in the nearshore and shelfal areas may well have been triggered by slumping and submarine sliding on the basin margin.

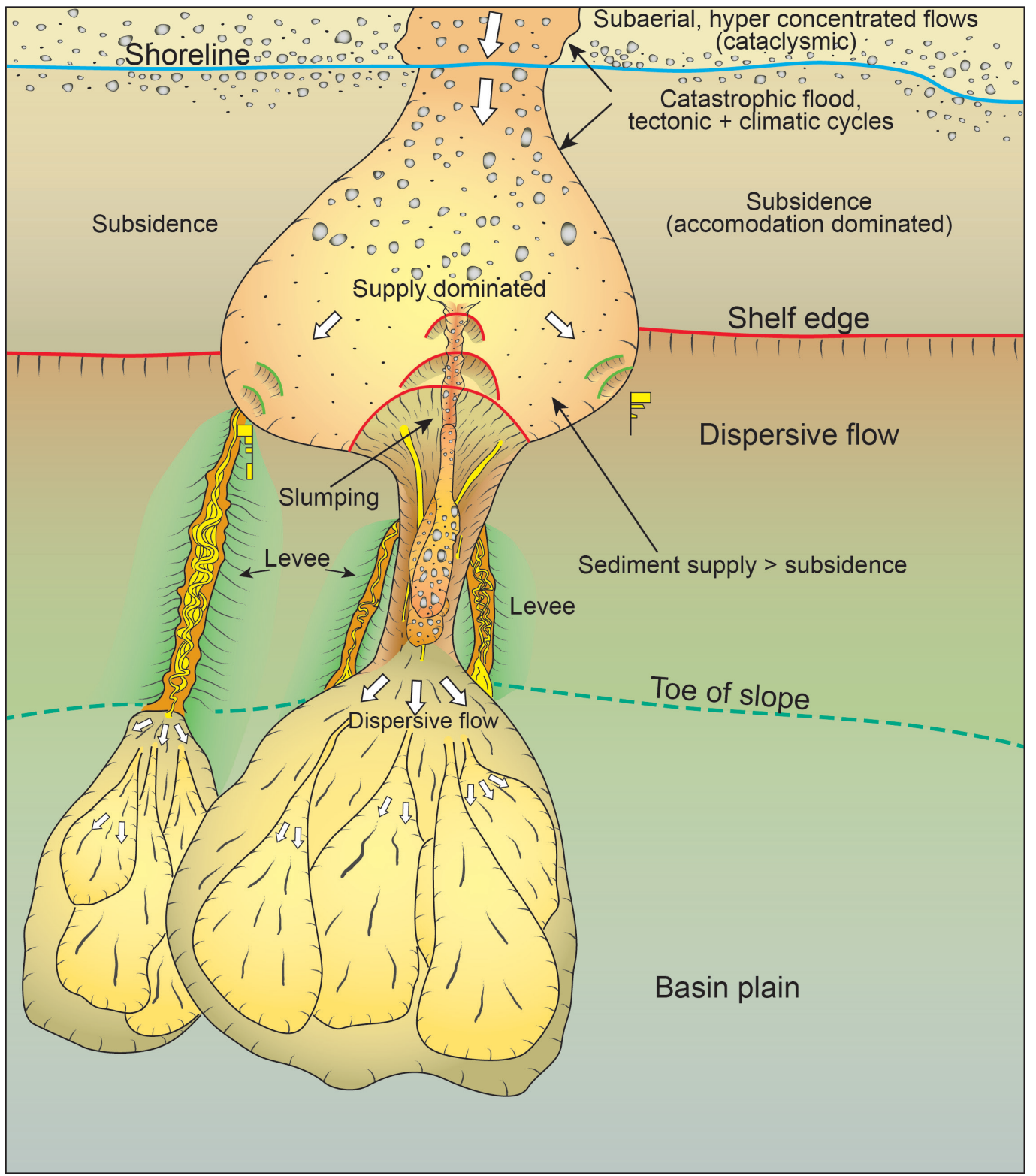

Figure 11. Depositional model with suggested areal distribution of facies in the Åsenfjord mixed conglomerate-turbidite system. Note that the sediments deposited on the continental shelf are interpreted to result from the same catastrophic event as the conglomerates in the deep-marine succession and are regarded as an integral part of the turbidite system. No scale intended. 
If released by slumping, this implies that the slumps must have reached far enough into the shelf to reach the conglomerate material, and consequently also must have been of significant size. In such a case, shelf-crossing canyons may have acted as conduits for sediment transport. This situation represents 'drainage' of the source area from the seaward side of the basin, and does adequately explain the presence of both well-rounded clasts and the large angular blocks found in the deepmarine successions.

Given the island-arc setting, frequent earthquakes capable of triggering the release of large quantities of clastic material are to be expected (e.g., Gutierrez-Pasto et al., 2009). However, the fluvial catchment area cannot have been very large, but rather favours a region of steep topography with many small rivers and a narrow continental shelf. The tectonic activity may have been combined with climatic cyclicity involving periods of heavy rainfall or the collapse of natural dams. A more exotic explanation is that the sediments could have been made available to marine processes by tsunamis, triggered by seismic activity, submarine slides or giant rock falls on land; truly a catastrophic event, but this remains difficult to prove for the above-stated reasons. The actual triggering mechanism may never be known, even though seismogenic events are the most reasonable option, and we therefore limit the discussion to the stratigraphic signature left by the sudden release of large amounts of sediment and water. In any event, the 'catastrophic model' may largely explain the presence of thick successions of conglomerates in deep-marine environments. Depending on the amount of water available, the floods will probably last for a while and give rise to relatively long-duration, sustained, supersaturated flows to the basin. After a while the system will experience a subsequent decrease in water and sediment supply. The flood will eventually recede and this will cause a gradual back-stepping of the system until the water discharge becomes so small that the bulk of sediments will be stored in a landward

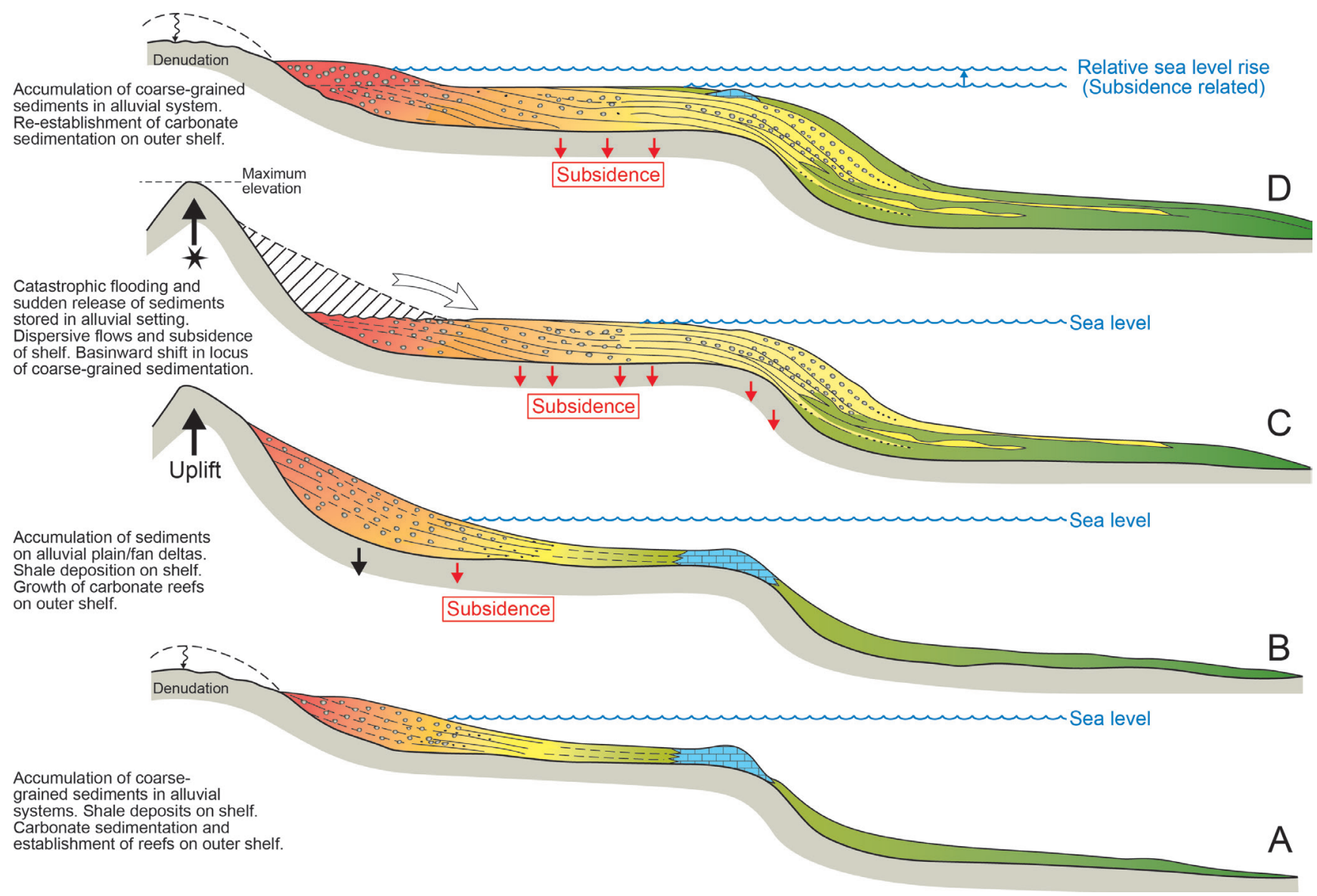

Figure 12. A schematic back-stripped profile with four stages of evolution illustrates the basin-filling successions of the Asenfjord turbidite system. The four stages are likely to be repeated in a cyclic manner. Note that a direct link between the alluvial and turbidite system is inferred. (A) Denudation of the landscape will result in accumulation of sediments in alluvial and fan-delta settings. Very little sediments are transported beyond the littoral zone during this stage and carbonate sedimentation prevails on the outer shelf. (B) Uplift of the source significantly increases the availability and accumulation of sediments in the alluvial system. (C) After reaching a threshold value, and possibly/likely triggered by a seismogenic/tectonic pulse, vast amounts of clastic material are flushed to the marine part of the basin during a catastrophic event. (D) When the alluvial system is evacuated for sediments, the system gradually attains normal conditions and carbonate sedimentation eventually resumes on the outer continental shelf. 
position again. In sequence-stratigraphic terms, this will be equivalent to a highstand situation and only mud and silt will then be carried to the deeper parts of the basin. When siliciclastic sediment delivery to the basin is at its minimum, carbonate sedimentation and reef growth will resume on the shelf.

The vertical stacking of several conglomerate units suggests that the deposition was cyclic in nature. The classical sequence-stratigraphic principles and relative sea level causative explanation for cyclicity are, however, less likely to have worked in this active tectonic setting. Instead, we propose a four-stage model where the stratigraphic signature is explained in terms of repetitive phases of uplift and erosion of the drainage area and where the 'shallow marine' features are included in the turbidite system via a transfer zone (Figs. 11, 12). This transfer zone may to some degree have spread out laterally on the shelf and accounts for the hummocky cross-beds, 'precursor beds' and dune forms signalling a sustained flow of sediments to the basin (Fig. 11).

If not released by slumping and canyon formation on the shelf, the release of sediments by catastrophic floods would have likely occurred around the time of maximum elevation and subsidence, which provided the source and accommodation for vast amounts of alluvium in the drainage area. The tectonic phases will naturally be long-term and provide the sediments available through time, whereas the triggering of individual conglomerateturbidite successions records a higher frequency signal (Fig. 12). Similar tectonically induced release of mass transport complexes has recently been suggested by Ortiz-Karpf et al. (2018).

Due to the post-depositional polyphase structuring of the area, measurement of paleocurrent flow directions may appear virtually meaningless. The exact basin physiography will therefore be difficult to reconstruct, but a scenario with both lateral sediment sources as well as an axial feeder system for turbidites and conglomerates is quite possible, as described by Pedersen (1981) (Fig. 13). The conglomerates represent relatively proximal parts of the depositional system, likely residing in canyons or larger sediment fairways fed from the basin margins. The thin-bedded turbidites and inferred distal facies, however, could very well have been transported in an axial system with contributions from far-distant sediment sources as well as from shorter-transported volcanogenic sediments from the island arc in the 'west' and the uplifted continental mainland to the 'east' (Fig. 13).

\section{Summary and conclusions}

- The Ordovician back-arc basin formation in Mid Norway is linked to changing subduction polarity in the Iapetus Ocean following Early Ordovician ophiolite obduction and gave rise to the gross distribution of land areas and uplift centres (Torsvik, 1996; Grenne \& Roberts, 1998; Hollocher et al., 2012; Hollocher et al., 2016). The short-term tectonics and proximity to a volcanic arc were important features

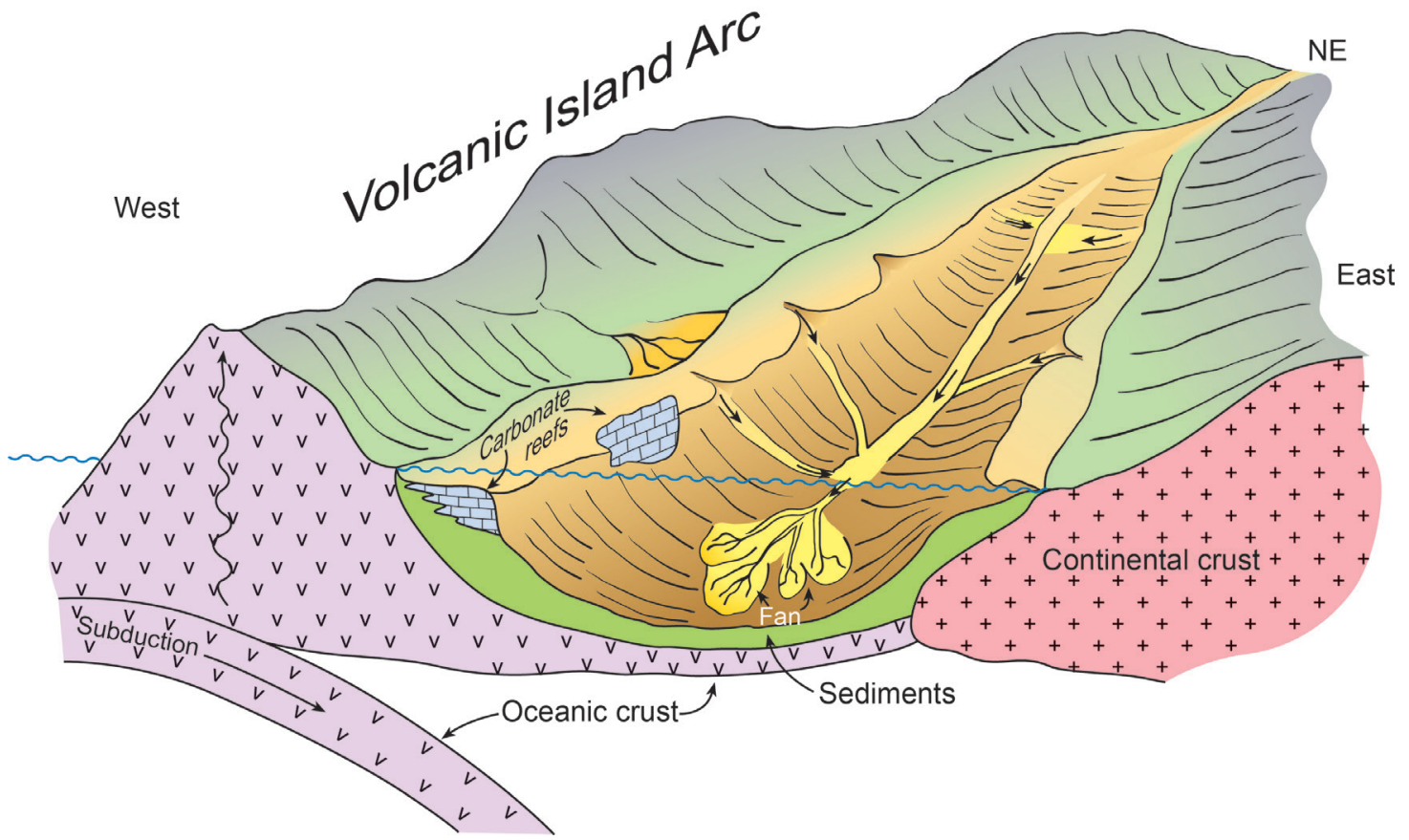

Figure 13. Simplified reconstruction of basin physiography and possible sediment routing during deposition. Both basin-axial and basintransverse depositional systems are possible in explaining the observed facies and facies associations. 
in the staging of sediments in near-shore and shelfal areas and their sudden release and transport to the receptor basin.

- The well-rounded clasts in the Hopla conglomerate are taken as evidence for long-term storage and reworking of coarse-grained sediments. The presence of carbonate clasts in the conglomerates suggests build-up of reef structures on the shelf and a very limited sediment supply to the shelf during periods of carbonate reef build up. The incorporation of large angular blocks of limestone, shale and sandstone suggests significant energy release during the pulses of sediment discharge.

- The presence of well-rounded clasts of carbonate and other lithologies of sedimentary origin show that the inferred high-energy flows were repeated events with enough time between events to allow the attrition and rounding of clasts in the source area as well as reworking of previous mainly fluvial deposits.

- The linked fluvio-turbiditic model differs from traditional views on sequence stratigraphy and turbidite deposits, and has the potential to fill in gaps in our present knowledge of deep-water depositional systems in tectonically active basins.

- By incorporating the thin-bedded turbidite successions and hummocky cross-bedded strata into the turbidite system, a holistic view on the turbidite system is introduced. These strata are interpreted to represent dispersive flows on the outer shelf and upper continental slope.

- The conglomerate beds have incised into the substrate and into each other and were thus probably confined to larger conduits (channel complexes), variably occupied by sandy turbidity currents and supersaturated conglomeratic flows.

- Laterally accreting sandstone units are interpreted as sinuous turbidite channels. Such channel sandstone beds are always found below major conglomerate successions and constitute an embryonic sediment fairway leading to the deep-marine environment.

- Sinuosity in the turbidite channels may have caused flow separation even for the coarsest grain sizes and may be an explanation for the interchangeable and juxtaposed matrix- and clast-supported conglomerates.

- The most distal turbidite units consist of sandstone beds and locally derived mass-transport deposits. These sediments probably dispersed freely on the sea floor and had no restriction on distribution other than the natural barriers set up by the relief of previous deposits.
Acknowledgements. Anna Pontén and Nils Erik Janbu at Statoil Research Center in Trondheim read and edited an earlier version of this manuscript and provided many useful comments and suggestions. Lars Reistad did a tremendous job in drafting of the figures. Deta Gasser and Gjis Henstra reviewed the manuscript thoroughly and their insightful comments significantly contributed to improvement of both text and figures. To all these persons, we offer our sincere thanks.

\section{References}

Abreu, V., Sullivan, M., Pirmez, C. \& Mohrig, D. 2003: Lateral accretion packages (LAPs): an important reservoir element in deep water sinuous channels. Marine and Petroleum Geology 20, 631-648. https://doi.org/10.1016/j.marpetgeo.2003.08.003.

Allen, J.R.L. 1970: Physical Processes of Sedimentation. Unwin, London, $248 \mathrm{pp}$.

Beaboef, R.T. 2004: Deep-water leveed-channel complexes of the Cerro Toro Formation, Upper Cretaceous, southern Chile. American Association of Petroleum Geologists Bulletin 88, 1471-1500. https://doi.org/10.1306/06210403130.

Bergström, S.M. 1979: Whiterockian (Ordovician) conodonts from the Hølonda Limestone of the Trondheim Region, Norwegian Caledonides. Norwegian Journal of Geology 59, 295-307.

Bergström, S.M. 1997: Conodonts of Laurentian faunal affinities from the middle Ordovician Svartsætra limestone in the Trondheim Region, Central Norwegian Caledonides. Geological Survey of Norway Bulletin 432, 59-69.

Bromley, R.G. 1996: Trace Fossils: Biology, Taphonomy and Applications. Chapman and Hall, London, $361 \mathrm{pp}$. https://doi.org/10.1007/978-1-4899-2875-7.

Bruton, D.L. \& Bockelie, J.F. 1980: Geology and paleontology of the Hølonda area, western Norway-A fragment of North America? In Wones, D.R. (ed.): The Caledonides in the USA, Virginia Polytechnic Institute and State University, Department of Geological Sciences Memoir 2, pp. 41-47.

Buller, A.T. \& Johnsen, S.O. 1982: Storm-influenced marine sandstones in the Ordovician Lower Hovin Group, Nord-Trøndelag. Norwegian Journal of Geology 62, 211-217.

Bullimore S., Henriksen, S., Liestøl, F.M. \& Helland-Hansen, W. 2005: Clinoform stacking patterns, shelf-edge trajectories and facies associations in Tertiary coastal deltas, offshore Norway: Implications for the prediction of lithology in prograding systems. Norwegian Journal of Geology 85, 169-187.

Fleuty, M.J. 1964: Tectonic slides. Geological Magazine 101, 452-456. https://doi.org/10.1017/S0016756800049840.

Gale, G.H. \& Roberts, D. 1974: Trace element geochemistry of Norwegian Lower Palaeozoic basic volcanics and its tectonic implications. Earth and Planetary Science Letters 22, 380-390. https://doi.org/10.1016/0012-821X(74)90148-4.

Gong, C., Wang, Y., Pyles, D.R., Steel, R.J., Xu, S., Xu, Q. \& LI, D. 2015: Shelf-edge trajectories and stratal stacking patterns: Their sequence- stratigraphic significance and relation to styles of deep-water sedimentation and amount of deep-water sandstone. American Association of Petroleum Geologists Bulletin, Bulletin 99, 1211-1243. https://doi.org/10.1306/01311513229.

Grenne, T. \& Roberts, D. 1998: The Hølonda Porphyrites, Norwegian Caledonides: geochemistry and tectonic setting of Early-Mid Ordovician shoshonitic volcanism. Journal of the Geological Society of London 155, 131-142. https://doi.org/10.1144/gsjgs.155.1.0131.

Gromet, L.P. \& Roberts, D. 2015: U-Pb zircon ages of felsic rocks in the Forbordfjell ophiolite fragment, Støren Nappe, Mid-Norwegian Caledonides. Norwegian Journal of Geology 96, 301-309. 
Gutierrez-Pasto, J., Nelson, H.C., Goldfinger, C., Johnson, J.E., Escutia, C., Eriksson, A. \& Morey, A.E. 2009: Earthquale control of Holocene turbidite frequency confirmed by hemipelagic sedimentation chronology of Cascadia and Northern California active continental margins. Society of Sedimentary Geology, Special Publication 92, 179-197.

Henriksen, S., Pontén, A., Janbu, N. \& Paasch, B. 2011: The importance of Sediment Supply and Sequence-stacking Pattern in Creating Hyperpycnal Flows. In Slatt, R.M. \& Zavala, C. (eds.): Sediment transfer from shelf to deep water - Revisiting the delivery system, American Association of Petroleum Geologists, Studies in Geology 61, pp. 129-152.

Henstra, G.A., Grundvåg, S.A., Johannessen, E.P., Kristensen, T.B., Midtkandal, I., Nystuen, J.P., Rotevatn, A., Surlyk, F., Sæther, T. \& Windelstad, J. 2016: Depositional processes and stratigraphic architecture within a coarse-grained rift-margin turbidite system: The Wollaston Forland Group, east Greenland. Marine and Petroleum Geology 76, 187-209.

https://doi.org/10.1016/j.marpetgeo.2016.05.018.

Gee, D. G., Guezou, J.-C., Roberts, D. \& Wolff, F. C. 1985: The centralsouthern part of the Scandinavian Caledonides. In Gee, D. G. \& Sturt, B. A. (eds.) The Caledonide Orogen - Scandinavia and related areas: John Wiley \& Sons Ltd, Chichester, pp.109-133.

Hickson, T.A. \& Lowe, D.R. 2002: Facies architecture of a submarine fan channel-levee complex: The Juniper Ridge Conglomerate, Coalinga, California. Sedimentology 49, 335-362. https://doi.org/10.1046/j.1365-3091.2002.00447.x.

Higgs, R. 2015: Enigmatic Brushy Canyon Formation, Delaware Basin, USA: Poor Outcrop Analog for Deep-Sea Turbidite Reservoirs. Search and Discovery Article \#51097.

Hiscott, R.N., Pickering, K.T., Bouma, A.H., Hand, B.M., Kneller, B.C., Postma, G. \& Soh, W. 1997: Basin-floor fans in the North Sea: sequence stratigraphic models vs. sedimentary facies; discussion. American Association of Petrologists Bulletin 81, 662-665.

Hollocher, K., Robinson, P., Walsh, E. \& Roberts, D. 2012: Geochemistry of amphibolite-facies volcanics and gabbros of the Støren Nappe in extensions west and southwest of Trondheim, western Gneiss region, Norway: A key to correlations and paleotectonic settings. American Journal of Science 312, 357-416.

https://doi.org/10.2475/04.2012.01.

Hollocher, K., Robinson, P., Seaman, K. \& Walsh, E. 2016: OrdovicianEarly Silurian intrusive rocks in the northwest part of the Upper Allochthon, Mid Norway: plutons of an Iapetan volcanic arc complex. American Journal of Science 316, 925-980. https://doi.org/10.2475/10.2016.01.

Hurich, C. A., Palm, H., Dyrelius, D., Kristoffersen, Y., Wolff, F. C. \& Roberts, D. 1988: Activation of Precambrian basement in the Scandinavian Caledonides: views from seismic reflection data. Norges geologiske undersøkelse Special Publication 3, 66-69.

Janocko, M., Nemec, W., Henriksen, S. \& Warchol, M. 2013: The diversity of deep-water sinuous channel belts and slope valley-fill complexes. Marine and Petroleum Geology 41, 7-34.

https://doi.org/10.1016/j.marpetgeo.2012.06.012.

Jobe, Z.R., Bernhardt, A. \& Lowe, D.R. 2010: Facies and architectural asymmetry in a conglomerate-rich submarine channel fill, Cerro Toro Formation, Sierra Del Toro, Magallanes Basin, Chile. Journal of Sedimentary Research 80, 1085-1108. https://doi.org/10.2110/jsr.2010.092.

Kane, I.A., McCaffrey, W.D. \& Peakall, J. 2008: Controls on sinuosity evolution within submarine channels. Geology 26, 287-290. https://doi.org/10.1130/G24588A.1.

Kiær, J. 1932: The Hovin Group in the Trondheim area. (With palaeontological contributions by Arbo Høeg, Hadding, Reed, Foerste, Strand and Størmer). Det norske Videnskabsakademi Skrifter 1, 1-175.

Kuenen, Ph.H. \& Menard, H. 1952: Turbidity currents graded and nongraded deposits. Journal of Sedimentary Petrology 22, 83-96.
Kuenen, Ph.H. \& Migliorini, C.I. 1950: Turbidity currents as a cause of graded bedding. Journal of Geology 58, 91-127. https://doi.org/10.1086/625710.

Li, P., Kneller, B.C., Hansen, L. \& Kane, I.A. 2016: The classical turbidite outcrop at San Clemente, California revisited: An example of sandy submarine channels with asymmetric facies architecture. Sedimentary Geology 346, 1-16. https://doi.org/10.1016/j.sedgeo.2016.10.001.

Lien, T., Walker, R.G. \& Martinsen, O.J. 2003: Turbidites in the Upper Carboniferous Ross Formation, western Ireland: reconstruction of a channel and spillover system. Sedimentology 50, 113-148. https://doi.org/10.1046/j.1365-3091.2003.00541.x.

Lippard, S.J. \& Roberts, D. 2010: Geochemistry and palaeogeographical setting of greenstone units on Frosta peninsula, Nord-Trøndelag, Central Norwegian Caledonides. Geological Survey of Norway Bulletin 450, 48-59.

Lopez, M. 2001: Architecture and depositional pattern of Quaternary deep-sea fan of the Amazon. Marine \& Petroleum Geology 18, 479486. https://doi.org/10.1016/S0264-8172(00)00071-4.

Mayall, M., Jones, E. \& Casey, M. 2006: Turbidite channel reservoirs - Key elements in facies prediction and effective development. Marine and Petroleum Geology 23, 821-841. https://doi.org/10.1016/j.marpetgeo.2006.08.001.

Mazzullo, J.M. \& Erlich, R. 1980: A vertical pattern of variation in the St. Peter Sandstone - Fourier grain shape analysis. Journal of Sedimentary Petrology 50, 63-70.

Martinsen, O.J., Lien, T., Walker, R.G. \& Collinson, J.D. 2003: Facies and sequential organisation of a mudstone-dominated slope and basin floor succession: The Gull Island Formation, Shannon Basin, Western Ireland. Marine and Petroleum Geology 20, 789-807. https://doi.org/10.1016/j.marpetgeo.2002.10.001.

Miall, A.D. 1991: Stratigraphic sequences and their chronostratigraphic correlation. Journal of Sedimentary Petrology 61, 479-505.

Mulder, T. \& Chapron, E. 2011: Flood deposits in continental and marine environments: Character and significance. In R.M. Slatt \& Zavala, C. (eds.): Sediment transfer from shelf to deep waterRevisiting the delivery system, American Association of Petroleum Geologists, Studies in Geology 61, pp. 1-30.

Mulder, T., Weber, O., Anschutz, P., Jorissen, F.J. \& Jouaneau, J.M. 2001: A few months-old storm-generated turbidite deposited in the Capbreton Canyon (Bay of Biscay, S-W France). Geo-Marine Letters 21, 149-156. https://doi.org/10.1007/s003670100077.

Mulder, T., Syvitski, J.P.M., Migeon, S., Faugeres, J.C. \& Savoy, B. 2003: Marine hyperpycnal flows: initiation, behaviour and related deposits, a review. Marine and Petroleum Geology 20, 861-882. https://doi.org/10.1016/j.marpetgeo.2003.01.003.

Mutti, E. 1992: Turbidite Sandstones. Amilcare Pizzi S.P.A. arti grafiche Cinsiello Balsamo, Milan, 275 pp.

Mutti, E. \& Ricci-Lucchi, F. 1975: Turbidite facies and facies association. In Mutti, E., Parea, G.C., Ricci-Lucchi, F., Sagri, M., Zanzucchi, G., Ghibaudo, G. \& Iaccarino, S. (eds.): Examples of Turbidite Facies Associations from Selected Formation of Northern Apennines, IX Int. Cong. IAS, Field Trip Guidebook, Nice, France, pp. 21-36.

Mutti, E., Davoli, G., Tinterri, R. \& Zavala, C. 1996: The importance of ancient fluvio-deltaic systems dominated by catastrophic flooding in tectonically active basins. Memori di Scienze Geologiche 48, 233291.

Mutti, E., Tinterri, R., Benevelli, G., Di Biase, D. \& Savanna, G. 2003 Deltaic, mixed and turbidite sedimentation of ancient foreland basins. Marine and Petroleum Geology 20, 733-755. https://doi.org/10.1016/j.marpetgeo.2003.09.001.

Mutti, E., Tinterri, R., Magalhaes, P.M. \& Basta, G. 2007: Deep-Water Turbidites and Their Equally Important Shallower Water Cousins. Search and Discovery Article \#50057.

Mutti, E., Bernoulli, D., Ricci Lucchi, F. and Tinterri, R. 2009: Turbidites and turbidity currents from Alpine 'flysch' to the continental margins. Sedimentology, 56, 267-318. 
Neuman, R.B. \& Bruton, D.L. 1989: Brachiopods and trilobites from the Ordovician Lower Hovin Group (Arenig/Llanvirn), Hølonda area, Trondheim Region, Norway: new and revised taxa and paleogeographic interpretation. Geological Survey of Norway Bulletin 414, 49-89.

Neuman, R.B., Bruton, D.L. \& Pojeta, J.Jr. 1997: Fossils from the Ordovician 'Upper Hovin Group' (Caradoc-Ashgill), Trondheim Region, Norway. Geological Survey of Norway Bulletin 432, 25-58.

Nilsson, L.P. \& Roberts, D. 2014: A trail of ophiolite debris and its detritus along the Trøndelag-Jämtland border: correlations and palaeogeographical implications. Geological Survey of Norway Bulletin 445, 101-117.

Odonne, F., Callot, P., Debroas, E.J., Sempere, T., Hoareau, G. \& Maillard, A. 2011: Soft-sediment deformation from submarine sliding: Favourable conditions and triggering mechanisms in examples from the Eocene Sobrarbe delta (Ainsa, Spanish Pyrenees) and the mid-Cretaceous Ayabacas Formation (Andes of Peru). Sedimentary Geology 235, 234-248. https://doi.org/10.1016/j.sedgeo.2010.09.013.

Ortiz-Karpf, A., Hodgeson, D. \& Jackson, C.A.L. 2018: Mass-Transport Complexes as Markers of Deep-Water Fold-and-trust Belt Evolutions: Insight from the Southern Magdalena Fan, Offshore Colombia. Basin Research 30, 65-88. https://doi.org/10.1111/bre.12208.

Payton, C.E. 1977: Seismic stratigraphy - applications to hydrocarbon exploration. American Association of Petroleum Geologists Memoir 26, Tulsa, Oklahoma, 519 pp.

Pedersen, P.Å. 1981: Resedimenterte konglomerater og turbiditter på overgangen mellomundre/øvre Hovin-gruppe (Llandeilo-Caradoc) $i$ Åsen-området, Nord-Trøndelag. MSc. thesis, University of Bergen, $127 \mathrm{pp}$.

Plink-Börklund, P., Mellere, D. \& Steel, R.J. 2001: Turbidite variability and architecture of sand-prone, deep-water slopes: Eocene clinoforms in the central basin, Spitsbergen. Journal of Sedimentary Research 71, 895-912. https://doi.org/10.1306/030501710895.

Porobski, S.J. \& Steel, R.J. 2006: Deltas and sea level change. Journal of Sedimentary Research 76, 390-403. https://doi.org/10.2110/jsr.2006.034.

Posamentier, H.W. \& Kolla, V. 2003: Seismic geomorphology and stratigraphy of depositional elements in deep-water settings. Journal of Sedimentary Research 73, 367-388.

https://doi.org/10.1306/111302730367.

Posamentier, H.W., Allen, G.P., James, D.P. \& Tesson, M. 1992: Forced Regression in a Sequence Stratigraphic Framework: Concepts, Examples, and Exploration Significance. American Association of Petroleum Geologists Bulletin 76, 1687-1709.

Quin, J.G. 2011: Is most hummocky cross-stratification formed by large-scale ripples? Sedimentology 58, 1414-1433. https://doi.org/10.1111/j.1365-3091.2010.01219.x.

Roberts, D. 1969: Trace fossils from the Hovin Groups, NordTrøndelag, and their bathymetric significance. Geological Survey of Norway Bulletin 258, 228-236.

Roberts, D. 1972: Penecontemporaneous folding from the Lower Palaeozoic of the Trondheimsfjord region, Norway. Geological Magazine 109, 235-242. https://doi.org/10.1017/S0016756800039273.

Roberts, D. 1975: The Stokkvola Conglomerate - a revised stratigraphical position. Norwegian Journal of Geology 55, 361-371.

Roberts, D. 1984: Nereites from the Ordovician rocks of the eastern Trondheimsfjord area, Central Norwegian Caledonides. Geological Survey of Norway Bulletin 396, 43-45.

Roberts, D. 1985: FROSTA, Berggrunnsgeologisk kart 1622-22 1:50000 foreløpig utgave. Norges geologiske undersøkelse.

Roberts, D.; Gee, D. G. 1985: An introduction to the structure of the Skandinavian Caledonides., The Caledonide Orogen - Scandinavia and related areas Part 1, pp. 55-68.
Roberts, D. \& Stephens, M.B. 2000: Caledonian orogenic belt. In Lundqvist, T. \& Autio, S. (eds.) Description to the bedrock map of Fennoscandia (Mid-Norden). Geological Survey of Finland Special Paper 28, pp.79-104.

Roberts, D., Walker, N., Slagstad, T., Solli, A. \& Krill, A. 2002: U-Pb zircon ages from the Bymarka ophiolite, Central Norwegian Caledonides, and regional implications. Norwegian Journal of Geology 82, 153-174.

Ryan, P.D., Williams, D.M. \& Skevington, D. 1980: A revised interpretation of the Ordovician stratigraphy of Sør-Trøndelag, and its implications for the evolution of the Scandinavian Caledonides. In Wones, D.R. (ed.): The Caledonides in the USA, Viginia Polytechnic Geological Sciences, Memoir 2, pp. 99-105.

Schumm, S.A. 1993: River response to base level change: Implications for sequence stratigraphy. Journal of Geology 101, 279-294. https://doi.org/10.1086/648221.

Siedlecka, A. 1967: Geology of the eastern part of the Meråker area. Geological Survey of Norway Bulletin 245, 22-58.

Slagstad, T., Pin, C., Roberts, D., Kirkland, C.L., Grenne, T., Dunning, G., Sauer, S. \& Andersen, T. 2014: Teconomagmatic evolution of the Early Ordovician suprasubduction-zone ophiolites of the Trondheim Region, Mid-Norwegian Caledonides. In Corfu, F., Gasser, D. \& Chew, D.M. (eds.): New perspectives on the Caledonides of Scandinavia and related areas, Geological Society of London, Special Publications 390, pp. 541-561.

Sloss, L.L. 1963: Sequences in the cratonic interior of North America. Geological Society of America Bulletin 74, 93-114. https://doi.org/10.1130/0016-7606(1963)74[93:SITCIO]2.0.CO;2.

Southard, J.B., Lambie, J.M., Federico, D.C., Pile, H.T. \& Weidman, C.R. 1990: Experiments on bed configurations in fine sands under bidirectional purely oscillatory flow, and the origin of hummocky cross-stratification. Journal of Sedimentary Petrology 60, 1-17.

Spjeldnæs, N. 1985: Biostratigraphy of the Scandinavian Caledonides. In Gee, D.G. \& Sturt, B.A. (eds.): The Caledonide orogen Scandinavia and related areas, John Wiley \& Sons, Chichester, pp. 317-329.

Stephens, M.B. \& Gee, D.G. 1989: Terranes and polyphase accretionary history in the Scandinavian Caledonides. Geological Society of America Special Paper 230, 17-30. https://doi.org/10.1130/SPE230-p17.

Strømmen, S.K. 1983: Marine avsetninger I under og øvre Hovingruppene (øvre ordovicium) på Frosta og Tautra I NordTrøndelag. MSc. thesis, University of Bergen, $305 \mathrm{pp}$.

Tolmacheva, T. J.\&.Roberts. D. 2007: NGU-Bulletin 447, pp. 5-15.

Torsvik, T.H., Smethurst, M.A., Meert, J.G., Van Der Voo, R., McKerrow, W.S., Brasier, M.D., Sturt, B.A. \& Walderhaug, H.J. 1996: Continental break-up and collision in the Neoproterozoic and Palaeozoic - A tale of Baltica and Laurentia. Earth-Science Reviews 40, 229-258. https://doi.org/10.1016/0012-8252(96)00008-6.

Torske, T. 1965: Geology of the Mostadmarka and Selbustrand area, Trøndelag. Geological Survey of Norway Bulletin 232, 1-83.

Törnebohm, A.E. 1896: Grunddragen af det centrala Skandinaviens bergbyggnad. Kongeliga Svenska Vetenskabs Akademiens Handlingar 28, 212 pp.

Uchman, A., Hanken, N.M. \& Binns, R. 2005: Ordovician bathyal trace fossils from metasiliciclastics in central Norway and their sedimentological and paleogeographical implications. Ichnos 12, 105-133. https://doi.org/10.1080/10420940590914534.

Vogt, T. 1945: The geology of part of the Hølonda-Horg district, a type area in the Trondheim Region. Norsk Geologisk Tidsskrift 25, 449528.

Walker, R.G. 1978: Deep-water sandstone facies and ancient submarine fans - models for exploration for stratigraphic traps. American Association of Petroleum Geologists Bulletin 62, 932-966.

Weimer, P. \& Link, M.H. (eds.) 1991: Seismic Facies and Sedimentary Processes of Submarine Fans and Turbidite Systems. Springer-Verlag, Berlin, Heidelberg, 447 pp. 
Weimer, P. \& Posamentier, H.W. (eds.) 1994: Siliciclastic Sequence Stratigraphy. Recent developments and Applications. American Association of Petreoleum Geologists Memoir 58, 492 pp.

Weimer, P., Bouma, A.H. \& Perkins, B.F. 1994: Submarine Fans and Turbidite Systems, Sequence Stratigraphy, Reservoir Architecture and Production Characteristics Gulf of Mexico and International. Gulf Coast Society of Sedimentary Geology Foundation 15th Annual Research Conference, 440 pp. https://doi.org/10.1007/978-1-4684-8276-8.

Wilgus, C.K., Hastings, B.S., Kendall, C.G.St.C., Posamentier, H.W., Ross, C.A. \& Van Wagoner, J.C. (eds.) 1988: Sea- Level Changes: An Integrated Approach. Society of Sedimentary Geology Special Publication 42, $407 \mathrm{pp}$.

Wolff, F.C. 1976: Geologisk kart over Norge, Berggrunnskart Trondheim, scale 1:250,000, Norges geologiske undersøkelse.

Wolff, F.C. 1984: Regional geophysics of the Central Norwegian Caledonides. Geological Survey of Norway Bulletin 397, 1-27

Wynn, R.B., Cronin, B.T. \& Peakall, J. 2007: Sinuous deep-water channels: genesis, geometry and architecture. Marine and Petroleum Geology 24, 341-387.

https://doi.org/10.1016/j.marpetgeo.2007.06.001.

Zavala, C., Arcuri, M., Meglio, M.Di., Gamero-Diaz, H. \& Contreras, C. 2011: A genetic facies tract for the analysis of sustained hyperpycnal flow deposits. In Slatt, R.M. \& Zavala, C. (eds.): Sediment transfer from shelf to deep water-Revisiting the delivery system, American Association of Petroleum Geologists Studies in Geology 61, pp. 31-51. 